NBER WORKING PAPER SERIES

\title{
THE SPILLOVERS, INTERACTIONS, AND (UN)INTENDED CONSEQUENCES OF MONETARY AND REGULATORY POLICIES
}

\author{
Kristin Forbes \\ Dennis Reinhardt \\ Tomasz Wieladek \\ Working Paper 22307 \\ http://www.nber.org/papers/w22307 \\ NATIONAL BUREAU OF ECONOMIC RESEARCH \\ 1050 Massachusetts Avenue \\ Cambridge, MA 02138 \\ June 2016
}

We would like to thank James Benford, Enrica Detragiache, Marco Lo Duca, Jas Ellis, Phil Evans, Linda Goldberg, Glenn Hoggarth, Sujit Kapadia, Luc Laeven, Lyndon Nelson, Roland Straub, and participants at the Carnegie-Rochester-NYU Conference on Public Policy, CBRTIMF-BIS conference on 'Macroprudential Policy: Effectiveness and Implementation Challenges', at the EMG-ECB Workshop on Global Liquidity and its International Implications, the ECB workshop on non-standard monetary policy measures, the IMF's 16th Jacques-Polak Annual Research Conference, the Bank of England Research Steering committee and Research Awayday for useful comments. We thank John Lowes for excellent assistance and advice with regard to the data. This paper was initially released as Bank of England External MPC Unit Discussion Paper No. 44. All remaining errors are our own. The views expressed in this paper are those of the authors, and not any institutions with which they are affiliated. The views expressed herein are those of the authors and do not necessarily reflect the views of the National Bureau of Economic Research.

At least one co-author has disclosed a financial relationship of potential relevance for this research. Further information is available online at http://www.nber.org/papers/w22307.ack

NBER working papers are circulated for discussion and comment purposes. They have not been peer-reviewed or been subject to the review by the NBER Board of Directors that accompanies official NBER publications.

(C) 2016 by Kristin Forbes, Dennis Reinhardt, and Tomasz Wieladek. All rights reserved. Short sections of text, not to exceed two paragraphs, may be quoted without explicit permission provided that full credit, including $\odot$ notice, is given to the source. 
The Spillovers, Interactions, and (Un)Intended Consequences of Monetary and Regulatory Policies

Kristin Forbes, Dennis Reinhardt, and Tomasz Wieladek

NBER Working Paper No. 22307

June 2016

JEL No. G21,G28

\begin{abstract}
$\underline{\text { ABSTRACT }}$
Have bank regulatory policies and unconventional monetary policies-and any possible interactions-been a factor behind the recent "deglobalisation" in cross-border bank lending? To test this hypothesis, we use bank-level data from the UK-a country at the heart of the global financial system. Our results suggest that increases in microprudential capital requirements tend to reduce international bank lending and some forms of unconventional monetary policy can amplify this effect. Specifically, the UK's Funding for Lending Scheme (FLS) significantly amplified the effects of increased capital requirements on cross-border lending. Quantitative easing did not appear to have a similar effect. We find that this interaction between microprudential regulations and the FLS can explain roughly $30 \%$ of the contraction in aggregate UK cross-border bank lending between mid-2012 and end-2013, corresponding to around 10\% of the global contraction in cross-border lending. This suggests that unconventional monetary policy designed to support domestic lending can have the unintended consequence of reducing foreign lending.
\end{abstract}

Kristin Forbes

MIT Sloan School of Management

100 Main Street, E62-416

Cambridge, MA 02142

and NBER

kjforbes@mit.edu

Dennis Reinhardt

Bank of England, Threadneedle Street, London EC2R 8AH

dennis.reinhardt@bankofengland.co.uk
Tomasz Wieladek

5 The North Colonnade

Canary Wharf

London E14 4BB

United Kingdom

tomaszwieladek@gmail.com 


\section{Introduction}

Global financial intermediation has changed significantly since 2008. Cross-border capital flows have contracted sharply (Figure 1), mainly due to a reduction in international bank lending. In contrast, FDI and international portfolio exposures have not declined by nearly as much and have bounced back since the 2008 crisis (Figure 2). This evolution in cross-border bank lending has been described as "financial deglobalisation" (Forbes, 2014) and "the great cross-border bank deleveraging” (Cerutti and Claessens, 2014). It can be divided into two stages: the sharp initial contraction that occurred during the crisis, and a more recent decline that began in 2012-what we refer to as the "second phase of banking deglobalisation". This most recent decline in international lending stands in sharp contrast to the relative stability in domestic bank lending over the same period, in both the UK and the world (Figure 3). Proposed explanations for the initial phase of banking deglobalisation include government intervention in the banking system (Rose and Wieladek, 2014), increased home bias (Giannetti and Laeven, 2012), reduced demand for loans, and reduced availability of wholesale funding for banks. ${ }^{1}$ Although a substantial literature has analysed various effects of regulatory and unconventional monetary policy, no previous work has examined whether these policies could be an important factor behind this contraction in global banking. ${ }^{2}$ Also, no other work has studied the second phase of banking deglobalisation. This paper aims to fill these gaps.

Many countries have significantly tightened bank regulations over the past few years (such as shown in Figure 4a for UK capital requirements) in order to strengthen the resilience of their financial systems. At the same time, many of the world's major central banks pursued unconventional monetary policies, such as quantitative easing (shown in Figure $4 \mathrm{~b}$ for the UK), and credit easing aimed at stimulating aggregate demand. While these policies are obvious candidate explanations for the contraction in cross-border bank

\footnotetext{
${ }^{1}$ See Cerutti and Claessens (2014) and Forbes (2014) for more detailed discussion of various potential causes.

${ }^{2}$ Most papers examining the impact of unconventional monetary policy focus on the effects on domestic and international financial market prices. Fratzscher, Lo Duca, and Straub (2013), Ahmed and Zlate (2013), and Koepke (2014) are some of the few examples of papers which instead assess the impact on global capital flows, especially to emerging markets.
} 
lending, there are several reasons why no other work has evaluated their effects empirically. First, distinguishing between cross-border loan supply and demand is difficult. Second, the temporal clustering of these different policies, in direct response to the financial crisis in most countries, makes disentangling their individual effects challenging using only time-series data. Finally, it is difficult (if not impossible) to obtain the necessary data on all the relevant policies in most countries.

This paper is able to address these challenges with a unique UK dataset combined with the policy responses of the UK over this period. The dataset includes external bank lending by country, which we have merged with detailed regulatory data ${ }^{3}$ on microprudential capital requirements, as well as with information on bank balance sheets and different forms of unconventional monetary policy. The resulting bank-country-time panel allows us to separate country-specific loan demand from supply via country-time effects (as in Aiyar et al., 2014). The UK also actively used different regulatory and unconventional monetary policies after the peak of the financial crisis: UK quantitative easing was conducted from 2009-2013; micro-prudential regulatory requirements were adjusted throughout; and the Funding for Lending Scheme (FLS), a policy designed to stimulate domestic lending, was introduced in July 2012. Finally, the UK is an ideal case study because UK-resident banks are at the heart of the global financial system and have played a major role in the deglobalisation of bank flows. ${ }^{4}$ Consequently, this dataset and the interplay of various UK policies over this time period allow us to identify and tackle the important question of what has caused the recent contraction in international bank lending.

Our results suggest that increases in capital requirements, and their interactions with certain types of unconventional monetary policies, have led to a significant reduction in international bank lending. We find that an increase in a bank's capital requirement of 100 basis points leads to a contraction in its external lending growth of

\footnotetext{
3 To construct a continuous series of microprudential capital requirements, it was necessary to merge data across three different regulatory forms, as reporting requirements changed substantially over this time period.

${ }^{4}$ UK banks provide more international loans (bank-to-bank assets) than any other country in the world, with $15 \%$ of international interbank activity booked in the UK and the average UK bank lending to 53 countries. Cross-border UK bank assets and liabilities both contracted by over 2\% of global GDP from 2008Q4 through 2013Q4-the largest contraction in global interbank activity corresponding to an individual country over this period.
} 
about 3.4\%. For banks which specialised in FLS-eligible lending (before the introduction of this policy), the effects of increased capital requirements were amplified by a significant amount. More specifically, the same increase in a bank's capital requirement led to a larger contraction in external lending under the FLS-with estimates suggesting a substantial amplification effect for the average bank. The evidence suggests that this is not the case for quantitative easing $(\mathrm{QE})$. The main results on the significant effects of increased capital regulations and its interaction with the FLS on international lending are robust to different data cleaning techniques and the inclusion of various control variables. These results are also robust to an alternative estimation framework aimed at addressing any potential endogeneity between capital requirements and international bank lending, as well as to regulatory changes in liquidity regulation over this time period (which could have also contributed to the contraction in bank-to-bank lending).

A more detailed analysis of the different components of the FLS program supports these main findings and provides additional detail on precisely how this type of credit easing interacted with and amplified the impact of capital regulations. This significant interaction between the FLS and increased capital regulations only occurred when the full FLS program - targeted at supporting both household and non-financial corporate (PNFC) lending-was in place. The interactions are less powerful during the second phase of the FLS-aimed at supporting only the much smaller component of PNFC lending. This is not surprising, since household mortgage lending is a much larger fraction of UK bank lending than PNFC lending. ${ }^{5}$

Moreover, we document that this effect is only present for international bank-tobank (but not bank-to-nonbank) lending, which is the type of lending behind the recent decline in cross-border banking flows since 2012 (as shown in Figures 5a and 5b). These results support the thesis that the interaction of increased capital requirements with the FLS (which began in 2012) may have contributed to the 'second phase of banking deglobalisation'. We also find evidence that these spillovers from changes in UK policy

\footnotetext{
${ }^{5}$ Bridges et al. (2014) note that mortgages make up 65\% of total UK domestic real sector lending, with PNFC lending making up the remaining $35 \%$.
} 
on international bank lending can vary across countries. For example, countries with stronger bank capital regulations experienced a smaller reduction in cross-border bank lending after changes in UK capital requirements.

In order to assess if our estimates based on UK microeconomic data can explain a meaningful amount of the total contraction in international bank flows, however, it is necessary to aggregate the results. Based on conservative assumptions, we calculate how cross-border bank lending would have evolved in the absence of increased capital requirements and their interaction with the FLS. This counterfactual ${ }^{6}$ suggests that international bank-to-bank lending would have been higher in the absence of tighter capital requirements, and substantially higher in the absence of their interaction with the FLS. This calculation suggests that the level of external UK (global) lending at the end of the first phase of the FLS in 2013 was approximately 30\% (10\%) lower as a result of these policies. This is striking as our estimates only capture the policy impact of one countryand many other countries were simultaneously increasing bank regulations and adopting various programs aimed at supporting domestic lending and the real economy. The effects of these policies - and their interactions — could explain a significant share of the reduction in international lending that occurred not only in the UK, but also in many other countries. $^{7}$

Overall, this series of results suggests that credit easing designed to support domestic lending, such as the UK's Funding for Lending scheme, might have the unintended consequence of amplifying the impact of microprudential capital requirements on external lending. The paper does not explicitly test for the domestic effects $^{8}$ of these policies, and instead focuses on the spillover effects to other countries. ${ }^{9}$ We show that the magnitude of these types of spillovers can be substantial and have global repercussions, even if the country of origin is relatively small. ${ }^{10}$ An assessment of

\footnotetext{
${ }^{6}$ Just as in any counterfactual exercise, the findings will be subject to the Lucas Critique, but they are nevertheless useful to demonstrate the scale and economic significance of our results.

${ }^{7}$ See Forbes (2014) for details on the contraction in cross-border lending by country over this period.

${ }^{8}$ Since these policies were explicitly aimed at domestic activity, our focus on the cross-border impact makes identification easier, since reverse causality is less of an issue.

9 The latter is easier to identify since the policy was not intentionally aimed at reducing cross-border lending.

${ }^{10} \mathrm{UK}$ GDP is roughly $3 \%$ of world GDP.
} 
the welfare consequences is beyond the scope of this paper, but the results have widespread implications for issues such as: the availability of credit, country vulnerability to foreign and domestic shocks, and the effectiveness of monetary policy.

The rest of the paper proceeds as follows. Section 2 describes the various regulatory and unconventional monetary policies adopted by the UK during this period, explains why these policies and their interactions could impact cross-border lending, and summarizes the data. Section 3 develops the empirical framework and presents the main results, including a series of robustness tests. Section 4 presents five extensions: an analysis of the different phases of the FLS; a breakdown of the impact on different types of international lending; a closer look at whether a country's macroeconomic and macroprudential characteristics affected these banking spillovers from UK policies; tests for the impact of changes in liquidity regulations; and an analysis to address endogeneity concerns. Section 5 calculates the aggregate effects on international bank lending implied by the results and Section 6 concludes.

\section{UK Bank Capital Regulations, Unconventional Monetary Policy and their Potential Interactions}

\subsection{Background on UK Policies}

Since the introduction of Basel I in 1988, bank capital requirements in most countries were set at a fixed value, at or above the minimum of 8 percent of riskweighted assets. In the UK, however, regulators also set bank-specific capital requirements, otherwise known as minimum trigger ratios ${ }^{11}$, to address operational, legal or interest rate risks, which were not accounted for in Basel I (Francis and Osborne, 2012). Within this regulatory framework, capital requirements were split into two pillars. Pillar 1 capital requirements are set at the minimum Basel I 8 percent level and are meant to capture credit and market risks. Pillar 2 capital requirements are supplementary add-

\footnotetext{
${ }^{11}$ A trigger ratio is the technical term for capital requirement, since regulatory intervention would be triggered if the bank capital to risk-weighted asset ratio fell below this minimum threshold.
} 
ons, meant to capture risks that were not contained in the first pillar, that differed across individual banks, and which were changed at the supervisors' discretion. They were reviewed either on an on-going basis or every 18 to 36 months. This regulatory regime was first implemented by the Bank of England, before responsibility was handed to the Financial Services Authority (FSA) in 1997.

These Pillar 2 capital requirements are the main variable of interest in this paper. Understanding how they are determined and what they represent is therefore important for the estimation and identification in this paper. The FSA-based regulatory decisions for banks relied on a system of guidelines called ARROW (Advanced Risk Responsive Operating frameWork), which covered a wide array of criteria related to operational, management, business as well as many other risks. ${ }^{12}$ Econometric analysis ${ }^{13}$, anecdotal evidence from senior policymakers' speeches ${ }^{14}$, and parliamentary inquiries into UK Bank failures ${ }^{15}$, all suggest that capital requirement changes within this regulatory framework for the period from 1998 to 2006 were mainly determined by factors other than loan growth or credit risk. Not surprisingly, following the failure of the British bank Northern Rock and the financial crisis that started in 2007, there was a greater focus on credit risk in setting microprudential capital requirements. ${ }^{16}$

During the time period analysed in this paper, UK authorities implemented two main forms of unconventional monetary policy: quantitative easing $(\mathrm{QE})$ and the Funding for Lending Scheme (FLS). ${ }^{17}$ Quantitative easing was initiated by the Bank of England in March 2009 in response to the fall in demand associated with the onset of the global

\footnotetext{
12 The ARROW approach also encompassed prudential risks, but this was not one of the core supervision areas.

${ }^{13}$ Aiyar et al. (2014) show that, while bank size and writeoffs appear to be important determinants of the level of capital requirements in the cross-section, bank balance sheet variables can typically not predict quarterly time variation in capital requirements. Similarly, Aiyar et al. (2015) estimate a bank panel VAR model on PNFC loan growth and capital requirement changes. They find evidence of causality running from changes in capital requirements to loan growth, but not vice versa. ${ }^{14}$ In his high-level review of UK financial regulation prior to the financial crisis of 2008, Lord Turner (then chief executive of the FSA), concluded that: 'Risk Mitigation Programs set out after ARROW reviews therefore tended to focus more on organisation structures, systems and reporting procedures, than on overall risks in business models' (Turner, 2009). 15 The inquiry into the failure of the British bank Northern Rock concluded that 'under ARROW I there was no requirement on supervisory teams to include any developed financial analysis in the material provided to ARROW Panels' (FSA, 2008). 16 This is discussed in more detail in Section 3.1 and our regression analysis considers how changes in bank-specific credit risk and international exposures might affect a banks' Pillar 2 capital requirement. Section 4.5 reports an analysis aimed at addressing any potential bias resulting from endogeneity.

${ }^{17}$ Earlier versions of this paper also investigated the impact of forward guidance, which was implemented at the end of the period. Measuring and calibrating forward guidance is difficult, however, and results using different approaches were generally insignificant and not robust to various iterations of the model.
} 
financial crisis in the UK. Under this program the Bank of England purchased a preannounced stock of sovereign debt. ${ }^{18}$ To avoid issues arising from the lack of stationarity, we identify changes in quantitative easing in our econometric analysis by using announcements on the flow of purchases.

The second main form of unconventional monetary policy was credit easing in the form of the Funding for Lending Scheme. This program was announced in June 2012 and coordinated between the Bank of England and Her Majesty's Treasury (HMT). This was specifically designed to increase bank lending by ensuring that high bank funding costs and capital constraints within the British banking system did not impede lending to the UK's real economy. This scheme consisted of several components-which we exploit in our econometric approach to help better identify the impact of this policy. First, the FLS provided funding to participating institutions for an extended period at below market rates, which likely led to lower interbank funding costs and hence lower effective interest rates on mortgage and PNFC loans in the UK. ${ }^{19}$ Even institutions that did not directly participate in the scheme would presumably have benefited from this reduction in interbank funding costs. The cost at which banks were able to borrow from the FLS facility was decreasing in the amount of the Bank's "FLS-eligible" lending-which was initially defined as lending to PNFCs and households.

A second component of the program provided preferential capital treatment for specific FLS-eligible lending in order to stimulate domestic lending. More specifically, as discussed above, UK-regulated banks are subject to a minimum $8 \%$ capital requirement (Pillar 1) and bank-specific capital requirements (Pillar 2). These bank-specific capital requirements can be split into different components, one of which is the "capitalplanning buffer" (also referred to as Pillar 2b). Banks were expected to hold this capitalplanning buffer on top of the total minimum capital requirement (consisting of the $8 \%$ Pillar 1 requirement and any other Pillar 2 capital requirements). When the bank's actual

\footnotetext{
18 This was different than the US program of QE, which focused on the flow of asset purchases and included purchases of government debt, as well as mortgage-backed securities.

19 The FLS allows participants to borrow UK Treasury Bills in exchange for eligible collateral, which consists of all collateral eligible in the Bank's Discount Window Facility.
} 
buffer falls below the bank's planning buffer, this usually triggers heightened scrutiny from regulators. Under the FLS, however, banks were allowed to apply for permission to reduce this capital-planning buffer by the amount of capital that was pledged on FLSeligible lending. While the receipt of this Pillar $2 \mathrm{~b}$ offset was not automatic and banks had to apply for it, this option to offset capital buffers for certain types of lending under the FLS would likely have changed the value that banks attached to FLS-eligible versus other types of lending.

A final key aspect of the FLS was how it was changed over time. In response to the improvement in household credit availability and conditions and renewed momentum in house price inflation, the subsidy to household lending under the FLS was removed on January $1^{\text {st }} 2014$. More specifically, both components of the FLS (the eligibility to count towards the type of net lending that warrants additional borrowing allowances from the FLS, as well as the capital offset option) were ended for household lending, but not for PNFC lending (which had shown less improvement). It was hoped that removing the support for household lending, but keeping the program in place for PNFC lending, would encourage banks to lend more to PNFCs, including small businesses. These two different phases of the FLS therefore provide a natural experiment to further test and explore how various components of the policy affected cross-border lending.

Finally, unconventional monetary policy (in the forms of QE or the FLS) could interact with changes in microprudential regulation (in the form of bank capital requirements) to have different effects on domestic and external lending growth through their different effects on risk weights. The UK, as for all other European countries, adopted Basel II and the corresponding model-based risk weights. Unconventional monetary policy could affect these risk weights in a number of ways — such as by affecting the outlook for the UK macroeconomy, loan terms and interest rates. For example, for mortgage lending these risk weights are based on the loan interest rate, the risk of unemployment, and loan terms (such as the LTV ratio). Any of these variables could be affected by unconventional monetary policy, thereby providing a direct interaction between these policies, risks weights, and bank lending. 


\subsection{Why Capital Requirements, Unconventional Monetary Policy, and their Interactions could affect International Bank Lending}

Economic theory suggests that tighter capital requirements after the crisis could partially account for the observed reduction in cross-border lending. Figure 6a illustrates that a rise in capital requirements can lead to a decline in risk-weighted assets and lending. But for this to be the case, i) bank equity needs to be more expensive than bank debt; and ii) capital requirements need to be a binding constraint on a bank's actual capital choice. Theory ${ }^{20}$ and evidence ${ }^{21}$ suggests that this is the case. Indeed, a series of Bank of England research papers on the UK, summarized in Appendix A, documents the negative impact on loan supply following a rise in capital requirements. ${ }^{22}$ Taken at face value, the findings from this literature would suggest that the steep rise in microprudential capital requirements since 2009 would generate a substantial contraction in bank loans, split between domestic and external assets.

The decision on which type of lending to contract, however, may depend on the presence of unconventional monetary policies, including through their impact on relative risk weights. If equity is expensive and capital buffers binding, the only way to adjust quickly to higher capital requirements is to reduce risk-weighted assets. This is most easily achieved by reducing those loans with the highest risk weights. In contrast, reducing assets with a zero percent risk weight, such as government debt, will not reduce risk-weighted assets at all. Moreover, UK banks have adopted model-based risk weights since 2008, which are typically based on borrower risk and loan terms. These models typically suggest that the probability of default, and hence the risk weights, for mortgage

\footnotetext{
${ }^{20}$ Condition i) implies a failure for banks of the Modigliani-Miller (1958) theorem, as otherwise changes in capital requirements do not need to affect a bank's cost of funding. But economic theory provides reasons for why condition i) should be satisfied, such as asymmetric information (Myers and Majluf, 1984) and different tax treatment for debt and equity. ${ }^{21}$ Similarly, empirical work documenting the impact of adverse shocks to bank capital on loan growth, as in Bernanke (1983) and Peek and Rosengren (1997, 2000) provides support for this assumption. Several other empirical studies also suggest that condition ii) is likely to be satisfied, with wide-ranging evidence that capital requirements were a binding constraint on banks' choices of capital structure during the 1998-2011 period. See Appendix A.

${ }^{22}$ In theory, higher capital requirements could increase lending at banks with very low or negative net worth, particularly if they help to address the debt overhang problem. Similarly, in the medium-run, improvements in the stability of the banking system that result from higher capital requirements could improve banks' abilities to raise funds in the market. Given the time period of this study, however, the effect of the decline in loan supply is expected to dominate in the short run.
} 
lending increases in unemployment risk, the LTV ratio, and the loan interest rate. As illustrated in Figure 6b, if unconventional monetary policy lowers interest rates or improves the economic outlook and hence reduces the risk weight, it will skew an individual bank's incentives to reduce one type of lending over another in response to higher capital requirements. Conceptually, this is how policies such as quantitative easing could interact with changes in microprudential requirements.

The FLS, a type of credit easing, was specifically designed to reduce bank funding costs and increase bank lending in targeted sectors. The cost of funds borrowed directly from the facility was decreasing with the amount of the new FLS-eligible (i.e., household and PNFC sector) lending by the borrowing bank. This is likely to have contributed to a general decline in bank funding costs (see Churm et al., 2015). Moreover, the corresponding pass-through to interest rates should have had a direct negative impact on the probability of default and hence risk weights associated with UK bank loans, just like with QE. As discussed above, the FLS had an additional effect of providing preferential capital treatment for FLS-eligible lending. This differential treatment by loan type could have further reduced risk weights on FLS-eligible domestic lending. This would have made qualified domestic lending relatively less capital intensive than international lending. Figure $6 \mathrm{~b}$ shows that, through these channels, the FLS could have magnified the impact of coincident changes in microprudential capital requirements on external lending. Finally, when the definition of FLS-eligible lending was changed in 2014 to exclude household lending (but still included PNFC lending), this would be expected to weaken any impact of such policies on the transmission of capital requirements on crossborder lending. The effect of this change in the FLS could be substantive because household lending forms a relatively larger share of UK banks' balance sheets.

\subsection{Data}

Appendix B provides information on the data that is used for our main regression analysis. Table B1 defines each of the variables and explains how they were constructed. Table B2 provides summary statistics. Our main dependent variable of interest, country- 
specific cross-border bank lending, is volatile in its raw form, with some suspicious outliers in the growth rate of lending. ${ }^{23} \mathrm{We}$ therefore adopt several data cleaning strategies (with alternatives discussed in the sensitivity analysis). In our base case, we drop any growth rates of external lending that are greater than $100 \%$ in absolute value. We also drop small recipient countries (those with less than $£ 500$ million in received funds on average) and bank-country lending pairs if the stock of lending did not exceed $£ 1$ million on average. ${ }^{24}$ Figure 7 shows the histogram of changes in one of our main variables, the change in the bank-specific capital requirements, both before and after 2007. This figure suggests that the number of increases in capital requirements is greater during the more recent period.

\section{Empirical Framework and Central Results}

This section begins by discussing the framework to test each of the proposed hypotheses about how microprudential capital requirements and their interactions with unconventional monetary policies affect international bank lending. Then it reports the main results and a series of robustness checks.

\subsection{Empirical Framework}

Our central framework to test the proposed hypotheses about the effects and interactions of regulatory and unconventional monetary policy on cross-border bank lending is the following regression model:

$$
\begin{gathered}
\Delta l_{i j t}=\sum_{k=0}^{3} \Delta K R_{i, t-k}\left(\beta_{k}+\delta_{k} Q E_{t}+\mu_{k} F L S_{t}+\rho_{k} w_{i}+\sigma_{k}\left(F L S_{t} * w_{i}\right)\right)+\gamma\left(F L S_{t} * w_{i}\right) \\
+\Lambda F_{j t}+e_{i j t}
\end{gathered}
$$

\footnotetext{
${ }^{23}$ UK bank lending refers to the lending of both UK-owned banks and foreign subsidiaries in the UK, i.e., entities subject to UK capital regulation.

${ }^{24}$ We only consider observations of bank-lending pairs if the stock of lending exceeds a share of $0.2 \%$ in the current or the preceding quarter's total stock of external lending (rather than large percent changes relative to small stocks). Keeping only significant portfolios ensures that we focus on economically meaningful changes in external lending. The $0.2 \%$ is chosen because it is one tenth of the average portfolio share for UK banks (which is 2\%) - i.e., the average UK banks lend to 50 countries. Results are robust to choosing a higher threshold.
} 
where $\Delta l_{i j t}$ is the growth rate of lending by bank $i$ to country $j$ at time $t$. In other words, the dependent variable is bilateral cross-border lending by the UK-incorporated PRA regulated entity. $\Delta K R_{i t}$ is the rise $\mathrm{e}^{25}$ in bank $i$ s minimum capital requirement (in percent of risk-weighted assets) in quarter $t$. Following previous work by Aiyar et al. (2014), the contemporaneous value and three lags of this term are included to allow lending to adjust gradually to changes in the regulatory ratio. $Q E_{t}$ is the announced flow of asset purchases, scaled by 2009Q1 UK nominal GDP. This only varies with time, which means that, unless interacted, it is absorbed by the time effects. $F L S_{t}$ is a dummy variable that takes the value of zero until 2012Q2, and the value of 1 thereafter. This also only varies with time and is meant to capture the idea that during this time period, all UK banks benefited from the option to apply for beneficial capital weighting, regardless of their direct participation in the scheme. The key to identification is that the extent to which the enactment of the FLS will skew a bank's incentive to cut back one type of lending versus another will depend upon the fraction of FLS-eligible to total lending $w_{i}$ (which then merits the reduced risk weighting). ${ }^{26} F L S_{t}$ is therefore interacted with $w_{i}$, the pre-FLS 2012Q2 fraction of FLS-eligible to total lending on bank is balance sheet, to capture its effect. To complete the specification, these terms are also interacted with $\Delta K R_{i t}$ independently.

This simple design has one feature worth highlighting: $F_{j t}$, the country-specific, time-fixed effects, is a way of asking whether the same country in the same time period borrowing from multiple UK-incorporated banks experiences a larger decline in lending from the bank facing a relatively greater increase in minimum capital requirements. This

\footnotetext{
${ }^{25}$ Most studies of UK capital requirement changes (i.e. Bridges et al., 2014; Aiyar et al., 2014a) pool capital requirement increases and decreases into one variable. This is because for the time period that they consider (1997-2007), it is not possible to reject the null hypothesis that the sums of coefficients on capital requirement increases and decreases are the same. As shown in Appendix Table B3, however, this hypothesis can be rejected at the 5\% confidence level for the period 2010-2015. This may not be surprising given that banks may have held back on expanding lending when faced with a loosening in capital requirements in preparation of higher banking-system wide requirements due to the introduction of Basel III. Therefore, for the remainder of the paper, we only model and study the impact of capital requirement increases (tightening).

${ }^{26}$ The change in the relative risk-weights of cross-border to domestic lending only applies to new lending. The fraction of the existing stock of these types of lending on the balance sheet is likely to reflect a bank's business model. Clearly, if a bank specialises in domestic lending, one would expect a relatively larger pull back in non-core activities, such as cross-border bank lending. On the other hand, a bank that mostly specialises in cross-border bank lending would probably not cut back crossborder lending more relative to domestic lending. It is of course possible that banks chose to change their specialisation in response to the FLS. But given any lack of indication that this policy was permanent, this strikes us as unlikely.
} 
term is therefore the direct analogue of the firm-specific, fixed-effects methodology pioneered by Khwaja and Mian (2008) to absorb changes in demand conditions. Since the comparison is across banks for the same country in a given time period, all demand shocks in country $j$ at time $t$ should be absorbed by this term.

An important assumption in this regression model is that $\Delta K R_{i t}$ is exogenous with respect to external lending by bank $i$ in country j. Aiyar et al. (2014) document that the word 'cross-border lending' was not even mentioned in regulatory guidelines pre-2006. This concern is more likely after the global financial crisis, however, when regulators paid more attention to bank-specific vulnerabilities and adjusted capital requirements more regularly (as discussed in Section 2.1). We take two approaches to addressing any potential econometric bias from this reverse causality.

First, our main dependent variable of interest is cross-border bank lending by bank $i$ to country $j$ at time $t$. As discussed in Section 2.1, capital requirements can be split into two pillars; Pillar 1 which is set at the minimum Basel I 8 percent level and is meant to capture credit and market risks, and Pillar 2 which are supplementary add-ons, changed at the supervisors' discretion, and meant to capture risks not contained in the first pillar. Pillar 2 capital requirements, the main variable of interest in this paper, would therefore only be changed in response to external exposures to one individual country if these were not adequately captured by the credit risk component in the first pillar. Conceptually, one would therefore expect any omitted variable and endogeneity bias to be less severe for external than for domestic lending or total credit growth, and especially for external lending to one specific country. ${ }^{27}$

Nonetheless, endogeneity may still be a concern, so we also adapt a second approach that goes further and is discussed in detail in Section 4.5 and Appendix C. This extension explicitly tests for any effects of endogeneity and other bank-specific omitted variables by modelling the backward and forward-looking determinants of capital

\footnotetext{
${ }^{27}$ This could of course be different for lending to the home country of the bank, such as in the case of the Icelandic banks in the UK. Similarly, some countries might be riskier than others and prudential regulators may set capital requirements in response to very quickly growing exposure to one particular country. Country-time effects should pick up some of these concerns, but not all.
} 
requirements and separately identifying the exogenous and endogenous components of increases in capital requirements. We use the residuals from this analysis as a measure of increases in capital requirements that are exogenous and do not result from changes in balance sheet risk. Our main results using the alternative measure of capital requirements are very similar, and often stronger relative to the baseline, across a number of specifications. This is precisely what would be expected if the degree of endogeneity has become smaller under the alternative approach.

Finally, this main framework used in this paper easily maps into several different testable hypotheses. First, to examine how increases in capital requirements affect external lending, we sum the $\beta_{k}$ coefficients and use an $F$-test to assess if this sum is different from zero. Second, to assess how QE has affected the transmission of changes in capital requirements, we sum the $\delta_{k}$ coefficients and also use an $F$-test. Third, to test for the impact of the FLS interacted with capital requirements, we also sum the above with the $\sigma_{k}$ coefficients and perform another $F$-test. We can also test for independent effects of the FLS (with the $\gamma$ coefficient). This framework therefore allows us to simultaneously test for the effects of microprudential regulations, and how these microprudential policies have interacted with unconventional policies such as QE and the FLS.

Economic theory predicts that the sign of the main coefficient measuring the direct impact of increased capital regulations, $\sum_{k=0}^{3} \beta_{k}$, should be negative. If equity is expensive and capital requirements are a binding constraint on an individual bank's choice of capital structure, one would expect that an increase in capital requirements would generate a reduction in loan supply. As discussed above, QE would be expected to have a greater impact on domestic relative to external risk weights, so that reducing external lending would be a more effective way to respond to increased regulations than reducing domestic lending. In other words, QE would amplify the effect of increased regulations on external lending and the sign on $\sum_{k=0}^{3} \delta_{k}$ would be expected to be negative. ${ }^{28}$ The FLS probably reduced interbank funding costs, and hence loan terms and

\footnotetext{
${ }^{28}$ Note that a positive value of the QE variable is expansionary monetary policy. A negative coefficient is therefore consistent with amplifying the effect of changes in capital requirements.
} 
interest rates, in the UK. FLS-eligible lending also provided the option to apply for a capital offset to all banks, regardless of their participation in the scheme. For all of these reasons, the FLS would be expected to have had a much stronger impact on domestic, as opposed to external, risk weights. Therefore, the predicted sign on $\sum_{k=0}^{3} \sigma_{k}$ would also be negative, as the FLS would also amplify the effect of increased regulations on external lending.

\subsection{Baseline Results and Robustness Checks}

The resulting estimates of the model are presented in Table 1. Column 1 shows that increases in capital requirements have a negative and statistically significant impact on cross-border bank lending, as expected. ${ }^{29}$ Column 2 adds the FLS term and its various interactions. The coefficient on changes in capital requirements continues to be negative and significant at the $5 \%$ level, as is the coefficient where this is interacted with the FLS term and share of FLS-eligible lending. The sum of coefficients on the interaction is 28.62, which seems large at first sight. This estimate, however, is for a bank with a fraction value $\left(w_{i}\right)$ of 1 , meaning that this bank only does FLS-eligible lending. Such a bank would, of course, not engage in external lending and hence not enter our sample. A more useful way to interpret this estimate is for the value of the FLS interaction term for the average bank in the sample, which is 0.153 . This means that for the average bank, the relevant coefficient is -4.3 , which is of a similar magnitude as the coefficient on changes in capital requirements. In other words, the presence of the FLS would, for the average bank, roughly double the negative impact of increases in capital requirements on external lending.

Column 3 tests for a similar effect of QE. The sum of coefficients on the QE interaction has the expected negative sign, but is not significantly different from zero. This result is reinforced in columns 4 through 6, which each simultaneously control for

\footnotetext{
${ }^{29}$ The magnitude (of -3.39) is smaller than that reported in Aiyar et al. (2014). When we estimate our model up to 2006 only, however, as done in their paper, the magnitude of the coefficient is closer to theirs. One potential explanation for the smaller magnitude when more recent data is included is that the adoption of model-based risk weights introduced an additional margin of adjustment in response to changes in capital requirements.
} 
the effects of QE, the FLS and changes in capital regulations. The coefficients on the FLS and QE interaction terms remain negative in each specification, but only the FLS interactions are significant. Column 5 includes a number of additional controls for individual bank characteristics. Column 6 reports the same analysis, but for easier interpretation, rescales $w_{i}$ (the fraction of FLS-eligible, to total, lending) to take a value of one for the average bank. Since this scaling makes it easier to infer the effect for the average bank from the tables directly (as shown above), we will use this rescaling for the presentation of all subsequent results. Finally, column (7) shows that the point estimate for our main variable of interest increases when excluding the $\Delta \mathrm{KR}^{*} \mathrm{QE}$ interaction.

Table 2 reports a series of robustness checks to the baseline from column 6 in Table 1. These tests are particularly important in our analysis given the volatility and noise in the banking data, especially for international loan growth. Columns 1 and 2 in Table 2 show results when we winsorise the dependent variable at 1/99\% and at 5/95\%, respectively. Column 3 clusters by country-time, as opposed to by bank-time as done in the baseline. Column 4 shows estimates when the sample is restricted to larger banks, defined as banks with an average balance sheet in excess of 2 billion pounds sterling. In column (5), we exclude affiliates with a parent headquartered in the Euro Area (EA) and in column (6), we include an interaction of $\mathrm{KR}^{*} \mathrm{FLS}{ }^{*}$ Fraction with a dummy that is 1 if lending is to a country in the EA. Both of these extensions are aimed at testing if the coincident crisis in this region significantly impacts the key results. As expected, our country-quarter fixed effects appear to control sufficiently for demand in other parts of the world (including the EA) and the interaction with the EA dummy does not turn out to be significant or impact our key results. In column (7), we run the regression from 2008 Q3 onwards to make sure that the results hold in a post-crisis sample. In each of these robustness tests, the variable capturing the interaction of the FLS, FLS-eligible lending and increased capital requirements is negative and significant, confirming that the presence of the FLS amplified the negative impact of increases in capital requirements on cross-border lending. 
In columns (8) and (9), we perform two placebo tests to ensure that the timing of the results agrees with the timing of the FLS. In column (8), we examine the impact of switching the FLS dummy on in 2008 Q3 - before the FLS was announced. As expected, this yields different results. The coefficient drops in size and loses significance. In column (9), we let this adjusted dummy equal one until 2012 Q2 - i.e., the part of the post-crisis period before the FLS was introduced. Excluding the FLS period now yields a positive and insignificant coefficient on the main variable of interest, providing further assurance that our results are indeed driven by the introduction of the FLS.

The key results are robust across these various iterations in Tables 1 and 2, and the estimated magnitudes of the key coefficients are quite stable. Increases in capital regulation tend to decrease cross-border bank lending and the FLS significantly magnifies this effect of capital regulations on international lending. This magnification effect is substantial and estimated to roughly double the magnitude of the impact of increases in capital requirements for the average bank. QE may also have magnified the effects of capital regulations on cross-border bank lending, but any such impact is estimated to be substantially smaller and usually insignificant. Therefore, different unconventional monetary policies appear to have different effects. The Funding for Lending Scheme, a credit easing policy targeted at boosting domestic bank lending, appears to have had the consequence of reducing international bank lending.

\section{Five Extensions: Two Phases of the FLS, Different Types of External Lending,}

\section{Receiving-Country Characteristics, Regulatory Changes in Liquidity, and Addressing Endogeneity}

This section reports five extensions of our baseline model in order to address specific aspects of UK regulatory and unconventional monetary policies, as well as receiving-country policies, which could bias our results. First, it begins by analysing if results change across the different phases of the FLS, which targeted different types of lending. Second, it tests for different effects on different types of external lendingnamely bank-to-bank versus bank-to-nonbank international lending. Third, it controls 
for different macroeconomic, institutional, and regulatory policies in countries receiving UK bank lending. Fourth, it examines if changes in regulations related to liquidity regulation could affect the results. Finally, it ends with a more detailed discussion of potential endogeneity between external lending and capital requirements, including a series of additional results aimed at addressing these concerns.

\subsection{The Two Phases of the FLS}

As described in Section 2.1, the Funding for Lending Scheme was announced in June 2012, but changed on January $1^{\text {st }}$ 2014 - about half way through our sample period. More specifically, in response to an improvement in the housing market and household credit conditions, the Bank of England and HMT decided to reduce both the funding subsidy and the beneficial capital weighting for household lending. The preferential terms for PNFC (private non-financial corporate) lending, however, were maintained. Figures $8 \mathrm{a}$ and $8 \mathrm{~b}$ show the fraction of FLS-eligible lending during the two phases of the FLS. When household mortgage lending is included, the share of FLS-eligible lending with respect to the total balance sheet is clearly much larger. Therefore, we would expect that the impact of the FLS on relative risk weights, and hence the overall effects on external lending through the interaction with capital requirements, would become weaker after January 2014.

To test this, column 1 of Table 3 repeats the base case analysis from column 6 of Table 1, but includes two sets of FLS interaction terms: one set for the first phase of the program that included household and PNFC lending; and one for the second phase which only covers PNFC lending. The main coefficient of interest, the interaction between changes in capital requirements and FLS-eligible lending, continues to be significant for the first phase of the FLS. As expected, it is also slightly larger in magnitude than in the estimates that include the full period of the FLS program. On the other hand, the same interaction term is no longer significant in the second phase of the program-although the coefficient still has the same negative sign. This is intuitive, since mortgage lending is typically a much larger fraction of the average bank's balance sheet than PNFC lending. 
This result therefore provides some additional support that the estimation framework is capturing the effects of the FLS as discussed above.

One possible caveat to this conclusion is the introduction of the Basel III definition of capital in the EU, and hence the UK, in January 2014. This coincides with the onset of the second phase of the FLS. At first sight, this could affect the econometric results presented above. But it is likely that the transition to Basel III capital standards started well before the formal introduction in January 2014, since the details were known ahead of time. From an economic perspective, this regulatory change would have led to an additional tightening in capital standards. If changes in the FLS were irrelevant, we should therefore observe an even greater impact on external lending. But our findings of no significant effect are instead consistent with the interpretation that our econometric estimate reflects the impact of the second phase of the FLS, rather than the formal introduction of Basel III.

\subsection{Effects on Different Forms of External Lending}

Next, it is also possible to decompose external bank lending data (both in BIS and UK data), into lending to banks abroad and lending to non-banks abroad. Figures 5a and $5 \mathrm{~b}$ show these two series for all BIS reporting banks as an aggregate and for the UK's banking system. These figures suggest that much of the contraction in external bank lending, and virtually all of the contraction since 2012 (the "second phase" of bank deglobalisation) is due to a contraction in bank-to-bank, as opposed to bank-to-nonbank, cross-border lending.

To test if credit easing or regulatory policy had different effects on these different types of international bank flows, and in turn if this could explain these trends across different types of bank lending, columns 2 and 3 of Table 3 reestimate the baseline model, except now split the data into bank-to-bank and bank-to-nonbank lending. The coefficient on which we have been focusing - the interaction between changes in regulation and FLS-eligible lending, is only statistically significant for bank-to-bank lending, but not bank-to-nonbank lending. It is also only statistically significant for the 
first phase of the FLS, but not the second, as found in column 1. This interaction term is also larger in magnitude when estimated only for bank-to-bank lending than for the larger lending category. This result could arise from a number of factors, but it is noteworthy that the sharpest contraction in cross-border capital flows-which occurred in cross-border bank-to-bank lending-is for the type of flow most strongly affected by the introduction of the full FLS program (and its interaction with capital regulations). This supports the hypothesis that the FLS played a substantive role in explaining the second phase of banking deglobalisation.

\subsection{Impact of Receiving Country Characteristics}

The previous analysis has focused on how UK unconventional monetary policies have amplified the effect of UK capital regulations on the international lending of UK banks. But the policies and characteristics of the foreign countries that are receiving these loans could also interact with UK regulations and make them more or less susceptible to any spillovers. Avdjiev, Gambacorta, Goldberg and Schiaffi (2016) make this point when they show that tighter capital requirements shield a given country from the negative effects of global shocks on cross-border bank loans. Cetorelli and Goldberg (2012) also document how country characteristics affected how global banks reallocated liquidity internationally during the Global Financial Crisis. Could tighter capital requirements also shield a given country from the effects of changes in another country's policies that affect its international bank lending? And could other country-specific characteristics—such as its loan demand, domestic institutions, capital controls, and other regulatory policieseither mitigate or magnify the spillover effects of UK policies on UK cross-border bank lending?

To test if receiving-country characteristics affect the extent of spillovers from UK capital regulations, we focus on the variables that Koepke (2014) highlights as domestic "pull factors" affecting cross-border bank lending. More specifically, we test for any significant impact of: domestic macroeconomic indicators (GDP growth, domestic equity returns, and country risk), the quality of domestic institutions (based on a rule-of-law 
index), domestic macroprudential policies ${ }^{30}$ (capital regulation, loan-to-value ratio caps, and local currency reserve requirements), and/or or domestic capital controls (using a broad measure of all controls on capital inflows and outflows). Appendix Tables B1 and B2 provide more detailed definitions, data sources and summary statistics. Our goal is to test whether any of these characteristics of foreign markets affect the spillovers from UK regulatory policy, so we interact each of the variables above with the change in UK capital requirements $(\Delta \mathrm{KR})$. We continue to include all of the variables and interactions from the base case, including all of the bank controls, as shown in Table 1, column $6 .{ }^{31}$

The results from including these various controls for receiving-country characteristics are shown in Table 4. Columns (1) and (2) report results with the additional controls for domestic macroeconomic indicators and institutional quality, respectively. Columns (3) and (4) report results for the additional controls for macroprudential regulations and capital controls, respectively. Data on two of these macroprudential regulations (loan-to-value caps and local currency reserve requirements) is more limited and significantly reduces the sample size. These two variables are also not individually significant, and including them has no noteworthy impact on the other key results, so we drop them in the remaining specifications. Column (5) then includes the measures of macroprudential regulations and capital controls simultaneously. Column (6) includes all the variables and column (7) includes only the variables which are significant (at the $10 \%$ level) in at least one specification.

The signs for each of the coefficient estimates are consistent across specifications and suggest receiving country characteristics can be important. For example, the negative coefficients on country risk and capital controls, and positive coefficient on institutions, implies that after an increase in UK capital requirements, UK banks cut lending more to countries with higher country risk, more capital controls, and weaker institutions. The significance of these estimates, however, varies across specifications. The coefficient

\footnotetext{
30 We follow Avdjiev et al. (2016) and focus on these three measures of macroprudential regulations from the Cerutti et al. (2015) database that have a good cross-country coverage.

${ }^{31}$ Quarterly variables such as returns and CDS spreads are lagged by one quarter before being interacted with capital requirements. All cross-country variables (except indices) are winsorised at the $1 \%$ level.
} 
estimate which has not only a consistent sign, but is also statistically significant across all specifications, however, is the positive coefficient on capital regulations. This implies that after an increase in UK capital requirements, UK banks cut lending less to countries with stronger capital regulations.

This significant coefficient on the impact of domestic regulations supports the evidence in Avdjiev et al. (2016) that tighter capital requirements can "shield" a given country from the negative effects of shocks that originate outside the country's borders (although in this case, the shock originated in one country - the UK - instead of being global). These results are also consistent with recent evidence on the transmission of macroprudential policies, which finds that in some cases cross-border lending can enjoy a comparative advantage relative to domestic banks, as the foreign bank lending is not always captured by tighter domestic capital requirements (Buch and Goldberg, 2016; Reinhardt and Sowerbutts, 2015). ${ }^{32}$

To summarize, this extension provides some evidence that receiving country characteristics can affect the extent to which a country is affected by spillovers from changes in UK regulatory policies. Stronger macroprudential regulations, and possibly fewer capital controls, lower risk ratings and stronger institutions, can partially mitigate any spillover effects from changes in foreign regulatory policies. It is also worth noting that the key result from our base analysis-the significant negative coefficient on the interaction between capital regulations, the FLS and fraction of FLS lending, remains negative and significant in each specification. This suggests that even after controlling for a range of receiving-country characteristics, changes in UK regulatory and unconventional monetary policy can significantly affect cross-border lending.

\subsection{Impact of Regulatory Changes on Liquidity}

The reduction in international bank-to-bank lending during the first phase of the FLS coincides with changes to liquidity regulation in the UK. We believe that these are

\footnotetext{
${ }^{32}$ Consistent with the latter paper, there was no comparable significant effect for regulations on loan-to-value caps or reserve local currency reserve requirements, as shown in column (3).
} 
unlikely to impact the main results and are, if anything, more likely to lead us to underestimate the effect of the first phase of the FLS. Nonetheless, we perform two empirical tests to ensure that our results are not biased by the coincident changes in liquidity regulation.

Basel III introduced liquidity coverage ratios (LCR), meaning that banks need to hold a minimum fraction of high quality liquid assets on their balance sheets in order to cover outflows of liabilities over specific stress scenarios. The regulatory definition of high quality liquid assets (HQLA) includes government debt and central bank reserves, but not interbank market loans, in order to reduce systemic risks. The latter has been traditionally used by many banks for liquidity management purposes. It is therefore likely that there is some substitution away from external (as well as domestic) interbank debt in response to the introduction of LCR. In addition, banks could possibly sell illiquid assets (both externally and domestically) as this would increase the ratio of HQLA to stressed liability outflows. Within the European Union, the LCR was only introduced at $60 \%$ in January 2015, increasing on a graduated basis until full implementation.

The UK moved earlier than most countries in implementing liquidity regulations, however, by introducing individual liquidity guidance (ILG), a prudential liquidity policy similar to the LCR. ${ }^{33}$ There were two macroprudential changes to liquidity regulations in the UK: first, the ILG requirements were relaxed in June 2012, by widening the collateral eligible to count as liquid assets. Second, in June 2013, the FPC announced that it would reduce the required LCR in 2015 to $80 \%$, rising thereafter to reach $100 \%$ in 2018 . The long transition phase to the full LCR makes it unlikely that our main results, which are for the period 2012Q3-2013Q4, are impacted. In addition, with the UK's implementation, liquidity requirements were - as described above - actually loosened in June 2012 and 2013. This would incentivise banks to substitute away from interbank lending by less, which would cause our estimated effect of the FLS to understate the true effect.

\footnotetext{
${ }^{33}$ See Banerjee and Mio (2015) for a detailed description of the UK's ILG regime and an empirical analysis of the ILG on banks' sterling balance sheets. The ILG is, similar to the LCR, designed to make the banking system more resilient to liquidity shocks by requiring banks to hold a minimum quantity of high quality liquid assets (HQLA) consisting of cash, central bank reserves and government bonds to cover net outflows of liabilities under two stress scenarios lasting different periods.
} 
Nonetheless, to assess the possible impact of liquidity regulations, we perform two exercises. The first is already reported in columns (5) through (7) of Table 1, where we include the share of liquid assets in banks' balance sheets as a control variable. The variable is negative and insignificant, and does not meaningfully impact the results. For a second test, we use data on the UK's ILG regime to check whether the introduction of ILG or subsequent tightening of the ILG percent requirement has any bearing on our main results. Specifically, we define the variable $\Delta$ ILG as a dummy that is equal to 1 in the quarter when ILG requirements were introduced or tightened and 0 otherwise. To match the specification of capital requirements, we include the contemporaneous value and three lags of this dummy. The bottom of Appendix Table B4 reports the tests of joint significance. It shows that the introduction/tightening of ILG had a significantly negative, albeit quantitatively small, effect on external bank lending. Moreover, column (2) shows that the effect is insignificant for cross-border bank-to-bank lending, which is where the greatest contraction in international lending occurred (as discussed in Section 1 and shown in Figure 5). Most importantly, our main results on the interaction of the FLS with capital requirements are not affected.

\subsection{Potential Endogeneity between Capital Requirements and External Lending}

An important assumption in our main regression model in Section 3.1 is that $\Delta K R_{i t}$ is exogenous with respect to external lending by bank $i$ in country $j$. As discussed in Section 2.1 and Section 4.4, however, the regulation of capital requirements around the world has changed significantly since the Global Financial Crisis. There is now a greater focus on balance sheet and credit risks. In the UK's current regulatory regime, Pillar 1 capital requirements are meant to address credit and market risks directly. Changes in Pillar 2 capital requirements, the main variable of interest in this study, are made at the discretion of the regulator to address risks that are not believed to be captured in the Pillar 1 capital requirement. If the first pillar captured all of the credit and market risks contained in balance sheet variables, then one would expect changes in Pillar 2 to be orthogonal to changes/growth rates in balance sheet and credit risks. This section tests 
this proposition and then reports results from an alternative specification which attempts to control for any endogeneity between capital requirements and external lending.

To begin, we examine whether the current, lagged or annual growth rate of 31 different variables that supervisors could have taken into account in their regulatory decisions predict changes in Pillar 2 capital requirements. Appendix C discusses the estimation and approach in more detail. To summarize, we use single and Bayesian Model Averaging regressions to identify the most important predictors of increases in capital requirements. The results (in Appendix Table C2) suggest that the strongest predictors are domestic lending growth to the real sector, financial and operating charges, and other operating income. These variables alone explain $30 \%$ of the $R^{2}$ of increases in capital requirements. This suggests that the majority of capital requirement increases are due to non-balance sheet risk, in line with our initial assumption.

Nonetheless, there is still a valid concern about endogeneity, so we pursue a second and more formal approach to see if this could affect our central estimates. More specifically, we use the key variables and results from above to predict increases in capital requirements using two different models (as shown in Appendix Table C3 and discussed in more detail in Appendix C). We then use the residuals from these two regressions as two alternative measures of $\Delta K R_{j, t}$, which we refer to as 'Model 1' and' Model 2'. These should be more reflective of increases in capital requirements due to operational risk, as opposed to credit and market risk, and should therefore not be affected by changes in cross-border lending. In other words, these residuals are orthogonal to balance sheet characteristics by construction.

Table 5 reports regression results with these alternative and more exogenous measures of capital requirements than used in the base case. Before discussing the results, it is important to note that the baseline sample is different from the main regression sample. This is because supervisors adopted a new regulatory form, the FSA003 form, after the UK's financial crisis in 2008. This form is a critical source of information to identify key variables used in setting capital requirements during this relevant post-crisis period. The availability of this form causes the number of observations in our sample to 
shrink substantially from 47,421 to 13,411. Column 1 in Table 5 begins by evaluating if this change in the sample affects the main results (while still using our initial measure of changes in capital requirements). Reassuringly, the baseline results are robust to estimating our regression model on this much shorter sample, although now the estimated magnification effect of the FLS on changes in capital requirements is larger. ${ }^{34}$

Next, columns 2 and 3 show results when we use our constructed and more exogenous measures of increases in capital requirements, i.e., the residual measures based on the regressions that predict regulatory changes with detailed balance-sheet information. The sum of our main coefficients of interest, $\sum_{k=0}^{3} \sigma_{k}$, remains positive and statistically significant, suggesting that our main results are robust to addressing endogeneity. It is also worth noting that this coefficient is quantitatively larger than in column 1 . This could occur if any reverse-causality between external lending growth and changes in capital requirements generates an upward bias in $\sum_{k=0}^{3} \sigma_{k}$ in a reduced-form regression.

Some authors argue that the contemporaneous term in panel time-series regressions is subject to a greater endogeneity bias than the lagged dependent variables. ${ }^{35}$ Therefore, we re-estimate our baseline model, but drop the contemporaneous capital requirement term everywhere. The results are presented in columns (4) to (6) of Table 5, for the baseline estimates and then the two models controlling for endogeneity, respectively. There are no substantive differences from the baseline estimates. ${ }^{36}$

Then, in columns (7) and (8) of Table 5, we put the variables which were found to be important predictors of capital requirements in Table B3 directly into our main regression (instead of using the residuals from the estimates of changes in requirements). ${ }^{37}$ The results are again consistent with our baseline estimates.

\footnotetext{
${ }^{34}$ This is not surprising as these estimates, obtained with the shorter sample, are equivalent to removing a large number of zeros in the interaction term in our application.

${ }^{35}$ See for example, Cornett, Strahan and Tehranian (2011).

${ }^{36}$ For the application in this paper, it is of course impossible to know if we fail to model an important part of the transmission mechanism by omitting the contemporaneous term. For this reason, we follow the standard approach in this literature and include the contemporaneous term in the baseline regression. Nonetheless, it is reassuring to know that excluding this term does not significantly change our results.

${ }^{37}$ Specifically, we include the contemporaneous value and three lags to match the lag structure of capital requirement changes.
} 
The analysis so far has relied on backward-looking determinants of changes in capital requirements, since balance sheet data do not reflect a bank's future lending strategy. It is likely, however, that supervisors also consider forward-looking measures of international portfolio performance when setting capital requirements. To account for this potential source of endogeneity, we repeat the extension controlling for endogeneity, except now also include a measure of exposure-weighted changes in GDP forecasts (for the receiving countries). ${ }^{38}$ This variable is intended to capture any future changes in the economic outlook of those countries to which the bank is exposed. It is therefore a measure of future international portfolio performance, which supervisors may take into account when setting capital requirements today. In column (9) of Table 5, we report our second-stage results after including this exposure-weighted GDP forecast variable in the first-stage regression (reported in column (4) of Appendix Table C3). In column (10) of Table 5, we include this exposure-weighted GDP forecast variable directly in the regression. The coefficient on this variable is negative in the first-stage regression, consistent with the idea that a bank exposed to countries forecasted to perform more strongly than before is less likely to increase capital requirements. In both of the secondstage regressions predicting cross-border lending, the key results do not change significantly. ${ }^{39}$

To summarize, the issue of whether an explanatory variable is exogenous with respect to the dependent variable is often difficult to resolve in an applied economics paper. In the absence of appropriate instruments for our main variable of interest, we have modelled changes in bank-specific capital requirements as a function of a wide array of balance sheet and regulatory variables, both backward and forward looking, and used the residuals from those regressions as a more exogenous measure of changes in capital requirements. This exercise suggests that our baseline results are robust to concerns about endogeneity. This is not surprising given our theoretical prior that most of the credit risk

\footnotetext{
${ }^{38}$ GDP forecasts are from the historical IMF WEO database. The variable is defined as two-year ahead forecasted real GDP growth less last year's two-year ahead forecast. Exposure weights are calculated using the portfolio shares by bank and multiplying by the GDP forecast. We use the change in GDP forecasts (instead of their levels) because some banks might specialize in lending to emerging markets (with high growth rates), while others lend more to advanced economies (with lower growth rates). Our measure captures improving/deteriorating future portfolio performance while controlling for this. ${ }^{39}$ We have also checked that including GDP growth forecasts into Model 1 yields similarly robust results.
} 
exposure should have been reflected in the Pillar 1 capital requirement, so that movements in Pillar 2 capital requirements (our key explanatory variable) should reflect mostly non-balance sheet risks, and hence be exogenous with respect to bank balance sheet variables.

\section{Aggregate Effects on International Bank Lending}

The purpose of this paper is to asses if changes in regulation and credit easing contributed to the sharp deglobalisation in banking since the financial crisis, and especially since 2012. This contraction in cross-border lending is documented in aggregate BIS and UK banking-system data, but the analysis in this paper is based on individual UK bank balance sheet data. The granularity of these microeconomic data was critical to identify and estimate our model, but it raises a valid question whether the interaction we focus on in this paper is economically relevant in explaining the broader international macroeconomic trends. Next, we attempt to bridge this gap with an aggregation exercise. This requires a number of assumptions, and therefore the results should be taken as illustrative only.

In order to perform this exercise, we use our central results from the estimated regression model reported in column (1) of Table 3, which includes results for the different phases of the FLS. We use the estimates from this table of the impact of those coefficients which are statistically significant. Since only the sums of coefficients associated with $\left(F L S_{t} * w_{i}\right) \Delta K R_{i t}$ are statistically significant, only these terms are used for the aggregation exercise (and not the impact of the capital requirement itself). We then use, for each bank, the counterfactual growth rates together with initial stocks of total external lending in pound sterling as of 2011Q3 (one year before the FLS was introduced) to estimate a series of counterfactual stocks. The resulting series is then summed across banks to give an aggregate series of international bank lending by UK banks.

Figure 9a shows the resulting calculation of international bank lending after removing the estimated effects of the interaction of the FLS and increases in capital regulations (in red). Actual data on international bank lending is also shown on the figure 
(in blue). A comparison of the two lines suggests that aggregate external bank lending would have been substantially higher in the absence of interaction between the FLS and increased capital regulations. Specifically, external bank lending was $£ 1300$ bn before the introduction of the policies and fell to about $£ 1060$ bn by the end of 2013 . The red line shows a decline to only $£ 1130$ bn predicted in the absence of the FLS combined with increased regulations. In other words, the $£ 240 \mathrm{bn}$ decline in international bank lending would have been a decline of only $£ 170 \mathrm{bn}$ (or 30\% smaller) in the absence of these policies. Since the decline in UK external bank lending during this period accounts for a third of the decline in the corresponding BIS data covering most banking flows, this suggests that just the interaction of the FLS and UK capital requirements can explain about $10 \%$ of the global contraction in bank lending during this period. The magnitude of the drag on external bank lending from the FLS is therefore economically meaningful, not only for the UK, but globally

Finally, the results in Section 4.2 suggest that most of the negative effect of the FLS on international bank lending occurred through reductions in bank-to-bank lending (instead of bank-to-nonbank lending). Therefore, we repeat this aggregation exercise to focus on the estimated effects of the FLS on aggregate bank-to-bank lending. For this calculation, we use the estimated coefficients reported in column 2 of Table 3, which finds that changes in capital requirements $\left(\left(w_{i}\right) \Delta K R_{i t}\right)$, as well as its interaction with the FLS $\left(\left(F L S_{t} * w_{i}\right) \Delta K R_{i t}\right)$, are significant. We therefore remove the effects of both of these terms when constructing a counterfactual estimate for international bank lending.

The resulting calculations are shown in Figure 9b. The blue line shows actual international bank-to-bank lending. The green line shows estimated lending absent the effects of increased capital regulations, and the red line shows estimated lending absent the effects of increased capital regulations and its interaction with the FLS. The calculations suggest that external bank-to-bank lending would have been higher in the absence of increases in capital requirements. It would have been substantially greater in the absence of the FLS and its interaction with higher capital requirements. In fact, the 
FLS seems to have more than doubled the effect of tighter capital requirements on international bank-to-bank lending.

\section{Conclusions}

Following the Global Financial Crisis, many countries around the world strengthened their prudential policies to improve the resilience of their financial systems. Many of the world's major central banks also introduced quantitative and credit easing to stimulate demand, support lending, and boost growth. At the same time, international bank lending experienced a historically unprecedented contraction-not only in the initial phase of the crisis, but in a "second phase of deglobalisation" that started in 2012. This paper examines if these developments are related, using the experience of the United Kingdom as a case study.

While a number of papers have analysed the effects on domestic lending of recent changes in prudential policies, quantitative and credit easing, ${ }^{40}$ we instead focus on the effects of these policies on international lending. Cross-border lending has declined by substantially more than domestic lending since the 2008 crisis. Unlike previous work, we also focus on the second phase of banking deglobalisation (instead of the initial contraction in 2008/2009). Perhaps most innovative, we focus on the interactions between various forms of unconventional monetary policy and changes in microprudential capital requirements. Specifically, we investigate if policies such as quantitative easing and the UK's Funding for Lending Scheme amplified the impact of higher capital requirements on external lending.

Our results show that the interaction of increased capital requirements with quantitative easing may have contributed to a reduction in international lending, but any such effect is estimated to be insignificant, small in magnitude, and not robust to different perturbations of the model. In contrast, credit easing in the form of the FLS appears to have substantially magnified the contraction in external lending resulting from increased

\footnotetext{
${ }^{40}$ For evidence of how UK domestic lending was affected by changes in prudential regulation, see Aiyar et al. (2015) and Bridges et al. (2014); for evidence on the effects of the FLS and QE, see Churm et al. (2015). Also see the papers summarized in Appendix A.
} 
capital requirements. More specifically, our baseline estimates suggest that a 100 basis point rise in capital requirements reduced external loans by $3.4 \%$, and this effect roughly doubled in the presence of the FLS. These results are robust to a number of tests and extensions, including a model aimed at addressing potential endogeneity. We also find that the contraction in external lending, and primary effects of the FLS on external lending, occurred through reductions in bank-to-bank lending (as opposed to international bank-to-nonbank lending), consistent with the broader global contraction in international lending. An additional extension shows that the spillover effects of increased capital requirements were significantly smaller in receiving countries with stronger macroprudential regulation, especially in the form of increased capital regulations.

Finally, a back of the envelope aggregation of these results based on micro-level UK bank data indicates that the estimated effects of changes in UK capital regulations and the FLS on external bank lending were also important at an aggregate level. Indeed, these effects can explain a meaningful part of the contraction in international bank lending, especially in international bank-to-bank lending that occurred from mid-2012 to 2014. This paper does not asses these effects and interactions in other countries, but given that many countries around the world have also increased regulations, adopted quantitative and credit easing, and simultaneously experienced a reduction in their own cross-border lending, it is likely that the UK effects documented here also occurred elsewhere. When any such effects are aggregated across countries, they could go even further in explaining the second phase of banking deglobalisation.

Unconventional monetary policy, and its interaction with regulatory policy, can have important global spillovers. This paper does not, however, assess the welfare implications of these spillovers. ${ }^{41}$ This would require a complicated assessment of the various costs and benefits of international lending, as well as an analysis of any secondround effects of changes in UK prudential policies, the FLS, and quantitative easing (such

\footnotetext{
${ }^{41}$ For recent overviews of related issues, see Bussière, Schmidt and Valla (2016), Koepke (2015), and Shin (2013).
} 
as from stimulating domestic growth, which could support exports from other economies).

Our results do, however, clearly show that a policy targeted at boosting domestic lending can unintentionally reduce international lending. The magnitude of these spillovers can be significant, with global implications, even if the policy originated in a relatively small country. The analysis also shows that monetary policies can magnify the effects of bank-specific regulatory policies-an important interaction that is typically ignored by standard macroeconomic analysis. Future research could explore whether these types of interactions also occurred in other countries and in conjunction with which types of regulatory and unconventional monetary policies. 


\section{$\underline{\text { References }}$}

Ahmed, S, and Zlate, A (2013), 'Capital Flows to Emerging Market Economies: a Brave New World?' Working Paper No. 1081, Board of Governors of the Federal Reserve Board.

Aiyar, S, Calomiris, C and Wieladek, T (2014a), 'Does macro-pru leak? Evidence from a UK policy experiment,' Journal of Money, Credit and Banking 46(1), pages 181-214.

Aiyar, S, Calomiris, C and Wieladek, T (2015), 'How does credit supply react to bank capital requirements and monetary policy?', European Economic Review, forthcoming.

Aiyar, S, Calomiris, C, Hooley, J, Korniyenko, G and Wieladek, T (2014), 'The International Transmission of Bank Minimum Capital Requirements', Journal of Financial Economics, 113(3), pages 368-382.

Avdjiev, S, Gambacorta, L, Goldberg, L, and Schiaffi, S (2016), 'The Shifting Drivers of International Capital Flows', Unpublished manuscript.

Banerjee, R. N. and Mio, H. (2015), 'The impact of liquidity regulation on banks', Bank of England Staff Working Paper No. 536.

Bernanke, B (1983), 'Nonmonetary effects of the financial crisis in the propagation of the great depression,' American Economic Review 73, 257-276.

Bridges, J, Gregory, D, Nielsen, M, Pezzini, S, Radia, A and Spaltro, M (2014), 'The Impact of Capital Requirements on Bank Lending, 'Bank of England WP 486.

Buch, C, and Goldberg, L (2016), 'Cross-Border Prudential Policy Spillovers: How Much? How Important? Evidence from the International Banking Research Network', Manuscript.

Bussière, M, Schmidt, J. and Valla, N (2016), 'International Financial Flows in the New Normal: Key Patterns (and Why We Should Care).' CEPII Policy Brief No 10., March.

Cerutti, E and Claessens, S (2014), "The Great Cross-Border Bank Deleveraging: Supply Constraints and Intra-Group Frictions.” IMF Working Paper WP/14/180.

Cerutti, E, Correa, R, Fiorentino, E, Segalla, E (2015), 'Changes in prudential policy instruments: a new cross country database', Unpublished manuscript.

Cetorelli, N, and Goldberg, L (2012), 'Liquidity management of U.S. global banks: Internal capital markets in the great recession." Journal of International Economics 88: 299-311. 
Churm, R, Joyce, M, Kapetanios, G and Kostantinos, T (2015), "Unconventional monetary policies and the macroeconomy: the impact of the United Kingdom's QE2 and Funding for Lending Scheme.” Staff Working Paper No. 542.

Cornett, M, McNutt J, Strahan, P, and Teharanian, H (2011), 'Liquidity risk management and credit supply in the financial crisis.' Journal of Financial Economics, Vol 101, No. 2, p.297-312.

De Luca, G and Magnus, J.R (2011), 'Bayesian model averaging and weighted average least squares: equivariance, stability, and numerical issues.' The Stata Journal, 11, p. 518-544.

Doppelhofer, G, Miller, R and Sala-i-Martin, X (2004), 'Determinants of Long-Term Growth: A Bayesian Averaging of Classical Estimates (BACE) Approach', American Economic Review, 94(4, September), p. 813-35.

Fernández, A, Klein, M. W, Rebucci, A, Schindler, M, and Uribe, M (2015) 'Capital Control Measures: A New Dataset.'

Forbes, K (2014), “Financial deglobalisation?: Capital Flows, Banks and the Beatles,' Speech given at Queen Mary University, Nov, available at: http://www.bankofengland.co.uk/publications/Pages/news/2014/149.aspx

Francis, W and Osborne, $\mathbf{M}$ (2012), 'Capital Requirements and Bank Behaviour in the UK: Are there Lessons for International Capital Standards?', Journal of Banking and Finance, Vol. 36, pages 816-903.

Fratzscher, M, Lo Duca, M and Straub, R (2013), 'On the International Spillovers of US Quantitative Easing', European Central Bank Working Paper No 1557, June.

FSA (2008), 'The supervision of Northern Rock: a lesson learned review'. Mimeo.

Giannetti, M and Laeven, L (2012), 'The flight home effect: Evidence from the syndicated loan market during financial crises,' Journal of Financial Economics, Vol. 104, No 1, pages 23-43.

Khwaja, A and Mian, A (2008), 'Tracing the effect of bank liquidity shocks: evidence from an emerging market', American Economic Review, Vol. 98, No.4, pages 1413A42.

Koepke, R (2014), 'Fed Policy Expectations and Portfolio Flows to Emerging Markets.' IIF Working Paper.

Miller, $M$ and Modigliani, F (1958), 'The Cost of Capital, Corporation Finance and the Theory of Investment,' American Economic Review, Vol. 48, Pages 261-297. 
Myers, S and Majluf, N (1984), 'Corporate financing and investment decisions when firms have information that investors do not have,' Journal of Financial Economics, Vol. 13, Pages 187-221.

Peek, J and Rosengren, E (1997), 'The international transmission of financial shocks: The case of Japan,' American Economic Review, Vol. 87, Pages 495-505.

Peek, J and Rosengren, E (2000), 'Collateral damage: Effects of the Japanese bank crisis on real activity in the United States,' American Economic Review, Vol. 90, Pages 30-45.

Reinhardt, D, and Sowerbutts, R (2015), 'Regulatory Arbitrage in Action: Evidence from banking flows and macroprudential policy', Bank of England Working Paper No. 546.

Rose, A. and Wieladek, T. (2014), 'Financial Protectionism? First Evidence.' The Journal of Finance, Vol. LXIX, No. 5, Pages 2127-2149.

Shin, HS (2013), 'The Second Phase of Global Liquidity and Its Impact on Emerging Economies.' Mimeo, Princeton University, November.

Turner, A (2009), 'The Turner Review: A regulatory response to the global banking crisis' 
Table 1: Baseline Results

\begin{tabular}{|c|c|c|c|c|c|c|c|}
\hline & & & & ernal Lending & & & \\
\hline & (1) & (2) & (3) & (4) & (5) & (6) & (7) \\
\hline$\Delta$ Capital Requirements & $-3.394 * * *$ & $-4.014 * *$ & $-2.570^{*}$ & -2.430 & -2.136 & -2.136 & $-3.567^{*}$ \\
\hline$p-v a l$ & 0.00430 & 0.0272 & 0.0666 & 0.209 & 0.286 & 0.286 & 0.0561 \\
\hline$\Delta$ Capital Requirements ${ }^{*}$ FLS & & $5.099 *$ & & 3.621 & $4.737^{*}$ & $4.737^{*}$ & $6.004^{* *}$ \\
\hline$p-v a l$ & & 0.0550 & & 0.177 & 0.0778 & 0.0778 & 0.0232 \\
\hline$\Delta$ Capital Requirements * Fraction & & 0.568 & & -2.332 & -2.722 & -0.416 & -0.0280 \\
\hline$p-v a l$ & & 0.914 & & 0.654 & 0.609 & 0.609 & 0.973 \\
\hline$\Delta$ Capital Requirements * FLS * Fraction & & $-28.62 * *$ & & $-24.89 * *$ & $-28.21 * *$ & $-4.311 * *$ & $-4.761^{* *}$ \\
\hline$p$-val & & 0.0169 & & 0.0375 & 0.0225 & 0.0225 & 0.0119 \\
\hline$\Delta$ Capital Requirements * $\mathrm{QE}$ & & & -0.781 & -0.828 & -0.784 & -0.784 & \\
\hline$p$-val & & & 0.156 & 0.153 & 0.182 & 0.182 & \\
\hline FLS * Fraction & & 0.0170 & & 0.0157 & 0.0293 & 0.00447 & 0.00463 \\
\hline s.e & & $(0.0362)$ & & $(0.0362)$ & $(0.0362)$ & $(0.00554)$ & $(0.00554)$ \\
\hline Liquid Asset Share & & & & & -0.0336 & -0.0336 & -0.0337 \\
\hline & & & & & $(0.0223)$ & $(0.0223)$ & $(0.0224)$ \\
\hline Bank Size & & & & & $0.0225 * * *$ & $0.0225 * * *$ & $0.0221 * * *$ \\
\hline & & & & & $(0.00688)$ & $(0.00688)$ & $(0.00689)$ \\
\hline Commitment Share & & & & & $0.0394 * *$ & $0.0394 * *$ & $0.0396 * *$ \\
\hline & & & & & $(0.0198)$ & $(0.0198)$ & $(0.0198)$ \\
\hline Deposit Share & & & & & -0.0277 & -0.0277 & -0.0256 \\
\hline & & & & & $(0.0275)$ & $(0.0275)$ & $(0.0276)$ \\
\hline Writeoffs (Changes) & & & & & $-0.931 * *$ & $-0.931 * *$ & $-0.925 * *$ \\
\hline & & & & & $(0.451)$ & $(0.451)$ & $(0.454)$ \\
\hline Writeoffs (Changes, L) & & & & & -0.356 & -0.356 & -0.357 \\
\hline & & & & & $(0.434)$ & $(0.434)$ & $(0.436)$ \\
\hline Writeoffs (Changes, L2) & & & & & -0.0556 & -0.0556 & -0.0789 \\
\hline & & & & & $(0.409)$ & (0.409) & (0.409) \\
\hline Writeoffs (Changes, L3) & & & & & -0.575 & -0.575 & -0.609 \\
\hline & & & & & $(0.414)$ & $(0.414)$ & $(0.414)$ \\
\hline Observations & 47,421 & 47,421 & 47,421 & 47,421 & 47,421 & 47,421 & 47,421 \\
\hline R-squared & 0.13 & 0.134 & 0.133 & 0.134 & 0.135 & 0.135 & 0.135 \\
\hline Adjusted R-squared & 0.0341 & 0.0343 & 0.0343 & 0.0345 & 0.0356 & 0.0356 & 0.0354 \\
\hline Bank Controls & NO & NO & NO & NO & YES & YES & YES \\
\hline Bank Fixed Effects & YES & YES & YES & YES & YES & YES & YES \\
\hline Country-Time-Effects & YES & YES & YES & YES & YES & YES & YES \\
\hline Cluster & Bank-Time & Bank-Time & Bank-Time & Bank-Time & Bank-Time & Bank-Time & Bank-Time \\
\hline
\end{tabular}

Note: The table presents the estimated parameter values from fixed effects panel regressions. The dependent variable is the quarterly percentage change in external bank lending. The data are discussed in Section 2.3 and variables are discussed in Section 3.1 and Appendix B. Standard errors are clustered at the bank-time level. ${ }^{* * *}$ is significant at the $1 \%$ level, ${ }^{* *}$ at the $5 \%$ level and ${ }^{*}$ at the $10 \%$ level. The sample period is $1997 \mathrm{Q} 1$ to $2015 \mathrm{Q} 1$. 
Table 2: Robustness

\begin{tabular}{|c|c|c|c|c|c|c|c|c|c|c|}
\hline & \multicolumn{9}{|c|}{ Total External Lending Growth } \\
\hline & & (1) & (2) & (3) & (4) & (5) & (6) & (7) & (8) & (9) \\
\hline & & & & & Drop small & Exclude EA & Vis-à-vis EA & & Switch 'FLS' on 2008 Q3 & Switch 'FLS' on 2008 Q3 \\
\hline & & Winsorise at $1 \%$ & Winsorise at $5 \%$ & Different clustering & banks & banks & interaction & From 2008 Q3 & to $2015 \mathrm{Q} 1$ - Placebo test & to $2012 \mathrm{Q} 2$ - Placebo test \\
\hline$\Delta$ Capital Requirements & & -2.112 & -1.888 & -2.136 & -1.913 & -2.403 & -2.132 & -0.521 & -5.149 & -2.625 \\
\hline & p-val & 0.289 & 0.289 & 0.270 & 0.359 & 0.240 & 0.287 & 0.812 & 0.120 & 0.427 \\
\hline$\Delta$ Capital Requirements * FLS & & $4.716 *$ & $4.231 *$ & $4.737^{*}$ & 4.750 & $4.907 *$ & $4.752^{*}$ & 2.027 & 1.547 & -0.326 \\
\hline & p-val & 0.0781 & 0.0791 & 0.0752 & 0.102 & 0.0697 & 0.0772 & 0.453 & 0.616 & 0.909 \\
\hline$\Delta$ Capital Requirements * Fraction & & -0.410 & -0.390 & -0.416 & -0.486 & -1.211 & -0.415 & -0.238 & 1.003 & -2.389 \\
\hline & $\mathrm{p}$-val & 0.614 & 0.595 & 0.572 & 0.570 & 0.246 & 0.611 & 0.840 & 0.528 & 0.160 \\
\hline$\Delta$ Capital Requirements * FLS * Fraction & & $-4.315^{* *}$ & $-3.883^{* *}$ & $-4.311^{* * *}$ & $-4.501 * *$ & $-4.319 * *$ & $-4.229 * *$ & $-5.074 * *$ & -3.311 & 2.498 \\
\hline & p-val & 0.0222 & 0.0224 & 0.00672 & 0.0202 & 0.0312 & 0.0444 & 0.0127 & 0.117 & 0.197 \\
\hline$\Delta$ Capital Requirements * $\mathrm{QE}$ & & -0.783 & -0.689 & -0.784 & -0.821 & -0.704 & -0.785 & $-1.009 *$ & $-1.232^{*}$ & $-1.207^{* *}$ \\
\hline & p-val & 0.182 & 0.196 & 0.150 & 0.188 & 0.243 & 0.182 & 0.0824 & 0.0190 & 0.0254 \\
\hline$\Delta$ Capital Requirements * FLS * Fraction & * EA & & & & & & -0.317 & & & \\
\hline & $p$-val & & & & & & 0.819 & & & \\
\hline FLS * Fraction & & 0.00440 & 0.00294 & 0.00447 & 0.00642 & 0.00627 & 0.00448 & 0.00622 & 0.00510 & -0.00145 \\
\hline & s.e & $(0.00553)$ & $(0.00500)$ & $(0.00481)$ & $(0.00602)$ & $(0.00568)$ & $(0.00553)$ & $(0.00553)$ & $(0.00443)$ & $(0.00480)$ \\
\hline Observations & & 47,421 & 47,421 & 47,421 & 39,677 & 45,570 & 47,421 & 16,512 & 48,489 & 48,489 \\
\hline Adjusted R-squared & & 0.0359 & 0.0386 & 0.0356 & 0.0403 & 0.0359 & 0.0355 & 0.0302 & 0.0349 & 0.0349 \\
\hline Bank Controls & & YES & YES & YES & YES & YES & YES & YES & YES & YES \\
\hline Bank Fixed Effects & & YES & YES & YES & YES & YES & YES & YES & YES & YES \\
\hline Country-Time-Effects & & YES & YES & YES & YES & YES & YES & YES & YES & YES \\
\hline Cluster & & Bank-Time & Bank-Time & Country-Time & Bank-Time & Bank-Time & Bank-Time & Bank-Time & Bank-Time & Bank-Time \\
\hline
\end{tabular}

Note: The table presents the estimated parameter values from fixed effects panel regressions. The dependent variable is the quarterly percentage change in external bank lending. Column (1) winsorises the LHS variable at the $1 \%$ level. Column (2) winsorises the LHS variable at the 5\% level. Column (3) clusters standard errors at the country-time instead of the bank-time dimension. Column (4) excludes banks with less than £2bn balance sheet on average. Column (5) excludes affiliates with a parent headquartered in the EA. Column (6) includes an interaction of KR*FLS*Fraction with a dummy that is 1 if lending is to a country in the Euro Area. Column (7) runs the regression from 2008 Q3 onwards. Columns (8) and (9) are placebo tests. Column (8) checks whether switching on the FLS dummy in 2008 Q3 (before the FLS was announced) yields different results. Column (9) lets this adjusted dummy run only until 2012 Q2 - i.e. the part of the post-crisis period before the FLS was introduced. The data are discussed in Section 2.3 and variables are discussed in Section 3.1 and Appendix B. Standard errors are clustered at the bank-time level. ${ }^{* * *}$ is significant at the $1 \%$ level, ${ }^{* *}$ at the $5 \%$ level, and ${ }^{*}$ at the $10 \%$ level. The sample period is $1997 \mathrm{Q} 1$ to $2015 \mathrm{Q} 1$. 
Table 3: The Two Phases of the FLS

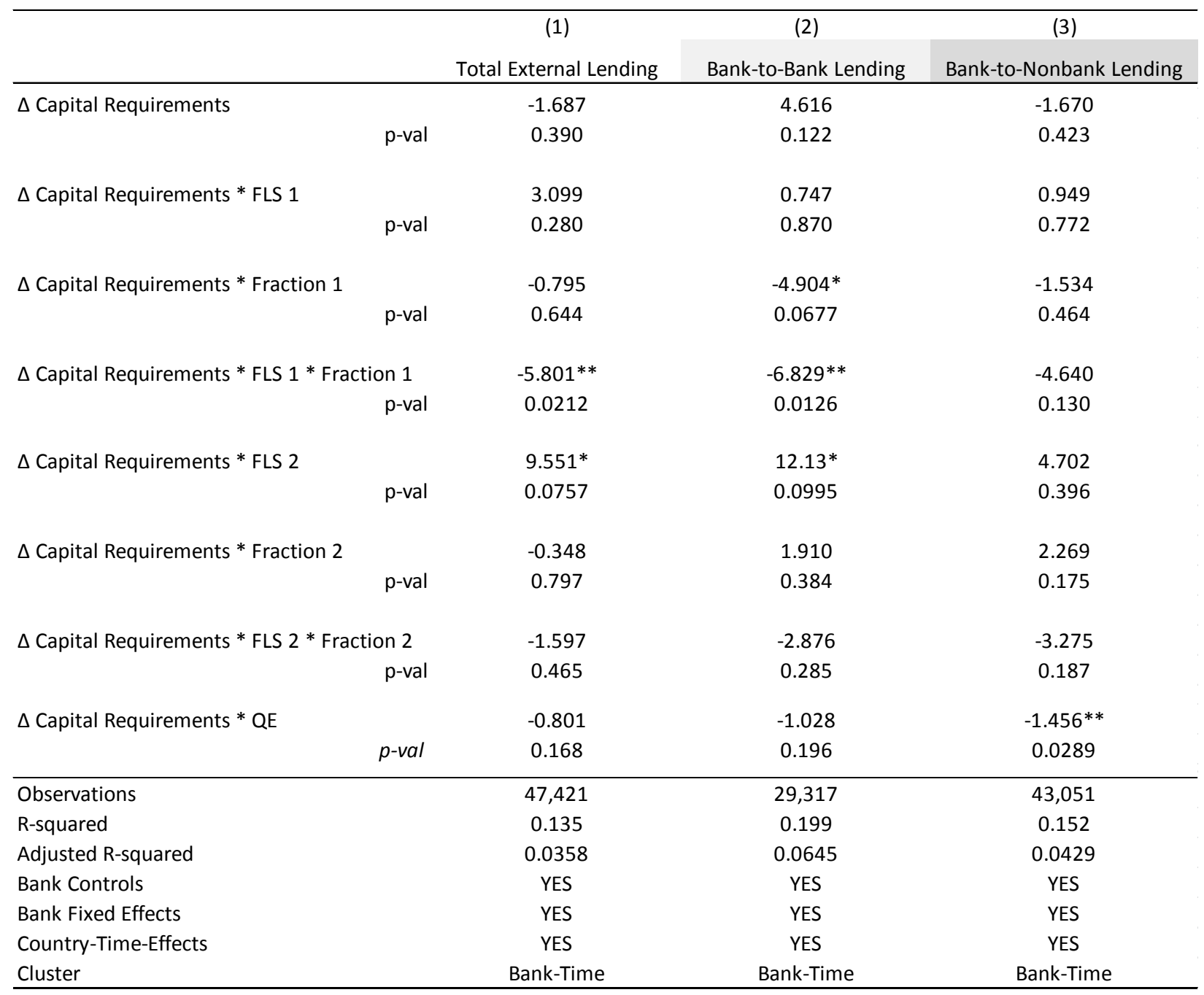

Note: The table presents the estimated parameter values from fixed effects panel regressions. In column (1), the dependent variable is the quarterly percentage change in external bank lending; in column (2), the quarterly percentage change in external bank lending to other banks; in column (3), the quarterly percentage change in external bank lending to nonbanks. The data are discussed in Section 2.3. Variables are discussed in Section 3.1 and Appendix B. Standard errors are clustered at the bank-time level. ${ }^{* * *}$ is significant at the $1 \%$ level, ${ }^{* *}$ at the 5\% level, and * at the 10\% level. The sample period is 1997Q1 to 2015Q1. 
Table 4: Controlling for Receiving-Country Characteristics

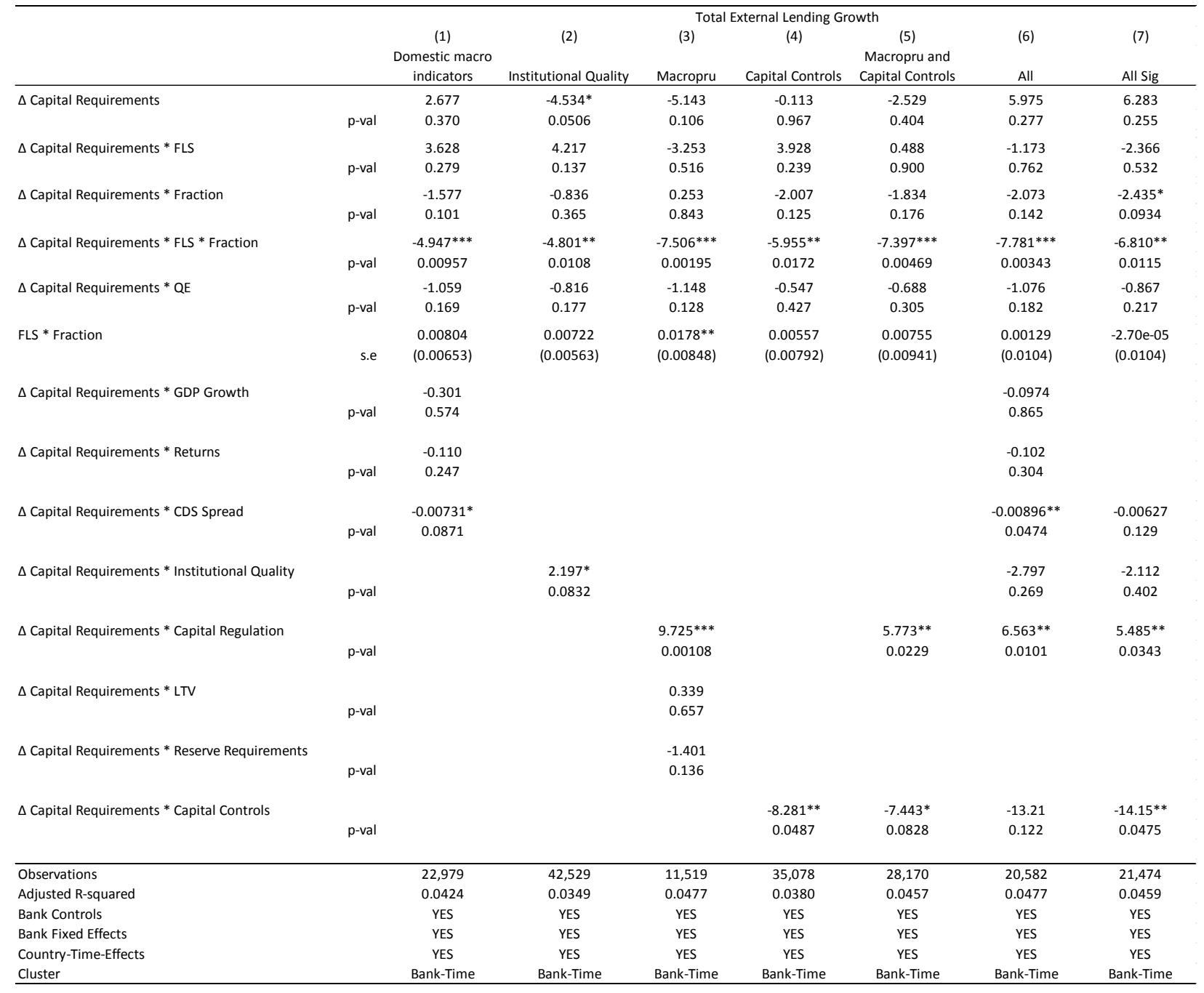

Note: The table presents the estimated parameter values from fixed effects panel regressions. The dependent variable is the quarterly percentage change in external bank lending. Column (1) includes interactions of capital requirement changes with GDP growth, stock market returns and CDS spreads (as proxies for loan demand). Column (2) includes a proxy for the institutional quality of a country, namely an indicator on the strength of the rule of law. Column (3) adds measures for the intensity of macroprudential regulation taken from Cerutti et al. (2015). Column (4) includes the overall capital account restriction index from Fernandez et al. (2015). Column (5) includes both capital regulation and capital controls. Column (6) keeps all variables except the previous insignificant prudential regulations, in which case the sample size drops by half. Column (7) keeps all variables that were significant at the $10 \%$ level in at least one specification. Quarterly variables, such as returns and CDS spreads, are lagged by one quarter before being interacted with capital requirements. The data are discussed in Section 2.3 and variables are discussed in Sections 3.1 and 4.3 and Appendix B. Standard errors are clustered at the bank-time level. ${ }^{* * *}$ is significant at the $1 \%$ level, ${ }^{* *}$ at the $5 \%$ level and ${ }^{*}$ at the $10 \%$ level. The sample period is 1997Q1 to 2015Q1. 
Table 5: Exogeneity of Capital Requirements

\begin{tabular}{|c|c|c|c|c|c|c|c|c|c|c|c|}
\hline & & $\begin{array}{l}\text { (1) } \\
\text { Baseline for Model } \\
\text { 1,2 Sample }\end{array}$ & $\begin{array}{c}\text { (2) } \\
\text { Model } 1\end{array}$ & $\begin{array}{c}\text { (3) } \\
\text { Model } 2\end{array}$ & $\begin{array}{c}\text { (4) } \\
\text { Drop } \\
\text { contemporaneous KR }\end{array}$ & \begin{tabular}{|c|}
$(5)$ \\
Drop contemporaneous KR \\
- Model 1 \\
\end{tabular} & $\begin{array}{l}\text { Total External Lendit } \\
\text { (6) } \\
\text { Drop contemporaneous } \\
\text { KR - Model } 2 \\
\end{array}$ & $\begin{array}{l}\text { G Growth } \\
\text { Include KR determinants } \\
\text { directly - Model 1 }\end{array}$ & $\begin{array}{l}(8) \\
\text { Include KR determinants } \\
\text { directly - Model } 2\end{array}$ & $\begin{array}{c}\text { (9) } \\
\text { Model } 2+\text { Forecast }\end{array}$ & $\begin{array}{c}(10) \\
\text { Include KR det. directly } \\
\text { Model } 2+\text { Forecast } \\
\end{array}$ \\
\hline$\Delta$ Capital Requirements & $p$-val & $\begin{array}{l}-0.477 \\
0.835\end{array}$ & $\begin{array}{l}4.440 \\
0.313\end{array}$ & $\begin{array}{l}4.019 \\
0.350\end{array}$ & $\begin{array}{l}-1.087 \\
0.583\end{array}$ & $\begin{array}{l}2.413 \\
0.463\end{array}$ & $\begin{array}{l}1.793 \\
0.580\end{array}$ & $\begin{array}{c}-1.073 \\
0.650\end{array}$ & $\begin{array}{l}-2.148 \\
0.378\end{array}$ & $\begin{array}{l}4.723 \\
0.253\end{array}$ & $\begin{array}{l}-2.149 \\
0.378\end{array}$ \\
\hline$\triangle$ Capital Requirements * FLS & $p$-val & $\begin{array}{l}3.093 \\
0.332\end{array}$ & $\begin{array}{l}9.621 \\
0.198\end{array}$ & $\begin{array}{l}3.137 \\
0.599\end{array}$ & $\begin{array}{l}3.339 \\
0.169\end{array}$ & $\begin{array}{l}2.023 \\
0.675\end{array}$ & $\begin{array}{l}0.971 \\
0.816\end{array}$ & $\begin{array}{l}3.804 \\
0.251\end{array}$ & $\begin{array}{l}4.744 \\
0.171\end{array}$ & $\begin{array}{l}8.560 \\
0.223\end{array}$ & $\begin{array}{l}4.748 \\
0.171\end{array}$ \\
\hline$\Delta$ Capital Requirements * Fraction & $p$-val & $\begin{array}{c}-0.323 \\
0.860\end{array}$ & $\begin{array}{l}-1.835 \\
0.528\end{array}$ & $\begin{array}{r}-1.676 \\
0.544\end{array}$ & $\begin{array}{l}0.368 \\
0.777\end{array}$ & $\begin{array}{l}-1.484 \\
0.458\end{array}$ & $\begin{array}{l}-1.457 \\
0.437\end{array}$ & $\begin{array}{l}0.790 \\
0.659\end{array}$ & $\begin{array}{l}1.190 \\
0.531\end{array}$ & $\begin{array}{l}-3.175 \\
0.310\end{array}$ & $\begin{array}{l}1.192 \\
0.533\end{array}$ \\
\hline$\Delta$ Capital Requirements * FLS * Fraction & $p$-val & $\begin{array}{c}-8.129^{* * *} \\
0.00635\end{array}$ & $\begin{array}{c}-13.97 * * \\
0.0154\end{array}$ & $\begin{array}{c}-11.33 * * \\
0.0252\end{array}$ & $\begin{array}{c}-7.956^{* * *} \\
0.000859\end{array}$ & $\begin{array}{l}-9.599 * * \\
0.0157\end{array}$ & $\begin{array}{l}-9.413 * * \\
0.0138\end{array}$ & $\begin{array}{c}-7.134^{* * *} \\
0.0137\end{array}$ & $\begin{array}{c}-9.356^{* * *} \\
0.00189\end{array}$ & $\begin{array}{c}-11.83^{* *} \\
0.0414\end{array}$ & $\begin{array}{c}-9.361^{* * *} \\
0.00206\end{array}$ \\
\hline$\triangle$ Capital Requirements * $\mathrm{QE}$ & $p$-val & $\begin{array}{l}-0.922 \\
0.119\end{array}$ & $\begin{array}{l}-3.434^{* * *} \\
0.000377\end{array}$ & $\begin{array}{c}-3.038^{* * *} \\
0.00136\end{array}$ & $\begin{array}{l}-0.469 \\
0.304\end{array}$ & $\begin{array}{c}-2.021^{* * *} \\
0.00614\end{array}$ & $\begin{array}{c}-1.824^{* * *} \\
0.00950\end{array}$ & $\begin{array}{l}-0.941^{*} \\
0.0991\end{array}$ & $\begin{array}{l}-1.062^{*} \\
0.0764\end{array}$ & $\begin{array}{l}-3.185^{* * *} \\
0.000690\end{array}$ & $\begin{array}{l}-1.063^{*} \\
0.0781\end{array}$ \\
\hline $\begin{array}{l}\text { FLS * Fraction } \\
\text { Exposure weighted GDP forecast }\end{array}$ & $\begin{array}{l}\text { s.e } \\
\text { s.e }\end{array}$ & $\begin{array}{c}0.00735 \\
(0.00843)\end{array}$ & $\begin{array}{l}-0.00501 \\
(0.00758)\end{array}$ & $\begin{array}{l}-0.00340 \\
(0.00760)\end{array}$ & $\begin{array}{c}0.00809 \\
(0.00707)\end{array}$ & $\begin{array}{l}-0.00246 \\
(0.00688)\end{array}$ & $\begin{array}{l}-0.00170 \\
(0.00677)\end{array}$ & $\begin{array}{c}0.0141^{*} \\
(0.00819)\end{array}$ & $\begin{array}{c}0.00894 \\
(0.00843)\end{array}$ & $\begin{array}{c}-0.00561 \\
(0.00761)\end{array}$ & $\begin{array}{l}0.00894 \\
(0.00843) \\
-0.0257 \\
(1.233)\end{array}$ \\
\hline Observations & & 13,411 & 13,411 & 13,411 & 14,241 & 14,241 & 14,241 & 13,324 & 13,370 & 13,411 & 13,370 \\
\hline Adjusted R-squared & & 0.0368 & 0.0369 & 0.0368 & 0.0357 & 0.0353 & 0.0356 & 0.0436 & 0.0376 & 0.0367 & 0.0375 \\
\hline $\begin{array}{l}\text { Bank Controls } \\
\text { KP }\end{array}$ & & YES & YES & YES & YES & YES & YES & $\begin{array}{l}\text { YES } \\
\text { YES }\end{array}$ & $\begin{array}{l}\text { YES } \\
\text { YyS }\end{array}$ & YES & $\begin{array}{c}\text { YES } \\
\text { YYS }\end{array}$ \\
\hline $\begin{array}{l}\text { KR determinants directly } \\
\text { Bank Fixed Effects }\end{array}$ & & $\begin{array}{l}\text { No } \\
\text { YES }\end{array}$ & $\begin{array}{l}\text { NO } \\
\text { YES }\end{array}$ & $\begin{array}{l}\text { No } \\
\text { YES }\end{array}$ & $\begin{array}{l}\text { NO } \\
\text { YES }\end{array}$ & $\begin{array}{l}\text { NO } \\
\text { YES }\end{array}$ & $\begin{array}{l}\text { NO } \\
\text { YES }\end{array}$ & $\begin{array}{l}\text { YES } \\
\text { YES }\end{array}$ & $\begin{array}{l}\text { YES } \\
\text { YES }\end{array}$ & $\begin{array}{l}\text { NO } \\
\text { YES }\end{array}$ & $\begin{array}{l}\text { YES } \\
\text { YES }\end{array}$ \\
\hline Country-Time-Effects & & YES & YES & YES & YES & YES & YES & YES & YES & YES & YES \\
\hline Cluster & & Bank-Time & Bank-Time & Bank-Time & Bank-Time & Bank-Time & Bank-Time & Bank-Time & Bank-Time & Bank-Time & Bank-Time \\
\hline
\end{tabular}

Note: The table presents the estimated parameter values from fixed effects panel regressions. The dependent variable is the quarterly percentage change in external bank lending. Column (1) reproduces our baseline result for the shorter period for which we could identify exogenous changes in capital requirements due to availability of regulatory data (2009 Q2 to 2013 Q4) - see Section 4.5. Column (2) uses the residuals from Model 1 in Table C3 as an exogenous measure of capital requirement tightening. Column (3) uses the residuals from Model 2 in Table C3 as an exogenous measure of capital requirement tightening. Column (4) drops contemporaneous capital requirement tightening and only retain the three lags. Columns (5) and (6) again use the residuals from Model 1 and 2 in Table C3, but now without contemporaneous changes in capital requirements. Columns (7) and (8) include the contemporaneous and three lags of the variables found to be important predictors of capital requirements in Table C3. Columns (9) and (10) repeat the exercise of columns (3) and (8) for the specification where we also include our measure of exposure-weighted GDP forecasts, either by including it as a determinant of capital requirements in Table C3 or directly into the regression. The exposure-weighted GDP forecast is from the IMF WEO database and defined as forecasted real GDP growth averaged over the following two years minus the same forecast last year. The data and variables are discussed in Sections 2.3 and 3.1, respectively, and Appendix B. Standard errors are clustered at the bank-time level. ${ }^{* * *}$ is significant at the $1 \%$ level, ${ }^{* *}$ at the $5 \%$ level, and ${ }^{*}$ at the $10 \%$ level. 


\section{Appendix A: Summary of Bank of England Research on Impact of Prudential Policy}

This survey briefly summarizes recent Bank of England studies on the impact of prudential policy on the banking system and the broader economy. Appendix Table A1 provides more detail about each paper.

Several Bank of England staff papers examine balance sheet adjustment in response to changes in UK microprudential capital requirements. If bank equity is more expensive than debt and changes to capital requirements are binding, a bank will either have to raise outside capital, retain earnings or cut back risk-weighted assets in response to a rise in capital requirements. These studies test the last implication and report the annual impact in response to a $1 \%$ rise in capital requirements. Frances and Osborne (2009) find that this $1 \%$ rise in capital requirements in 2002 would have led to a decline in aggregate lending (riskweighted assets) by $1.2 \%$ (2.4\%) four years later. Aiyar, Calomiris and Wieladek (2012) use more recent data and report that PNFC lending growth declines by $5.7 \%$. Bridges, Gregory, Nielsen, Radia and Spaltro (2014) find that commercial real estate, other PNFC and household lending contract by $8.07 \%, 3.86 \%$ and $0.94 \%$, respectively. Uluc and Wieladek (2015) report that individual mortgage loans contract by 5.1\%. Aiyar, Calomiris, Hooley, Korniyenko and Wieladek (2014) find that cross-border lending falls by 5.4\%. Bahaj, Bridges, Malherbe and O'Neil (2016) find a smaller impact when lending prospects are good and legacy assets healthy. Banerjee and Mio (2015) do not find an impact of individual liquidity guidance ratios on real economy lending. Despite different methods and datasets, all of these papers concur that a rise in capital requirements leads the affected bank to contract lending.

Credit substitution from foreign branches can offset this effect, however, either via direct competition (Aiyar, Calomiris and Wieladek, 2012) or by arbitraging the regulatory impact on their affiliated UK subsidiary (Aiyar, Calomiris and Wieladek, 2014). In aggregate, these channels are estimated to offset the negative loan supply impact of higher capital requirements by $40 \%$. Similarly, Reinhardt and Sowerbutts (2015) find evidence for leakages in a cross-country panel: foreign banks lend more to the non-bank sector in response to tightening in domestic macroprudential capital regulation. They do not find evidence for leakages in the case of lending standards regulation, which usually applies to all products sold in a country.

Therefore, whether changes in capital requirements have real effects depends on the scope of credit substitution. Indeed, Noss and Tofano (2014) find a significant impact on UK lending, but not real GDP, in a VAR model. De Marco and Wieladek (2015) study the impact on SME asset growth of a rise in the capital requirements of their main relationship bank with firmlevel data. They find that SMEs contract asset growth by between 3.5\% and 6.9\%, and that this is driven by a reduction in bank funding. Overall, this suggests that firms which are dependent on a single bank are probably most affected. 
Two recent papers examine how regulation taken abroad affects lending in the UK. Hills et al. (2016) find that macroprudential regulation in foreign countries does not affect aggregate UK domestic lending, consistent with the idea that the UK is a core business destination for most banks. However, more granular results show that foreign affiliates increase lending to UK households once there is a tightening in LTV regulation in their home countries.

Danisewicz, Reinhardt and Sowerbutts (2015) show that the organisational form of affiliates matters for spillovers to UK interbank lending, with foreign branches transmitting foreign capital regulation to a greater degree than foreign subsidiaries.

Evidence on the interactions between prudential policy and the transmission of monetary policy has been more limited (with the exception of this paper). Aiyar, Calomiris and Wieladek (2014) find evidence that changes in interest rates only affect small banks in the UK, while changes in capital requirements affect all banks, suggesting that monetary policy would not be able to offset negative effects of prudential policy via the bank lending channel. De Marco and Wieladek (2015) confirm these findings with firm-level data. 


\section{Appendix Table A1}

\begin{tabular}{|c|c|c|}
\hline Paper & Title and Authors & Key Finding \\
\hline FSA No. 36 & $\begin{array}{l}\text { Bank regulation, capital and credit supply: } \\
\text { Measuring the impact of prudential regulation, } \\
\text { 2009, William Francis and Matthew Osborne }\end{array}$ & $\begin{array}{l}\text { Changes in capital requirements pose binding constraints on banks } \\
\text { actual capital ratios. A one percent rise in capital requirements in } 2002 \\
\text { would have led to a decline in aggregate lending (total risk-weighted } \\
\text { assets) by } 1.2 \%(2.4 \%) \text { four years later. }\end{array}$ \\
\hline BoE No. 445 & $\begin{array}{l}\text { Does macropru leak? Evidence from a UK policy } \\
\text { experiment, 2012, Shekhar Aiyar, Charles } \\
\text { Calomiris and Tomasz Wieladek }\end{array}$ & $\begin{array}{l}\text { A one percent rise in capital requirements leads to a bank-specific } \\
5.7 \% \text { contraction in PNFC lending within a year. In aggregate, credit } \\
\text { substitution (leakage) by foreign branches offsets this effect by one } \\
\text { third. }\end{array}$ \\
\hline BoE No. 485 & $\begin{array}{l}\text { Identifying channels of credit substitution when } \\
\text { bank capital requirements are varied, 2014, } \\
\text { Shekhar Aiyar, Charles Calomiris and Tomasz } \\
\text { Wieladek }\end{array}$ & $\begin{array}{l}\text { Credit substitution operates through a regulatory arbitrage (foreign } \\
\text { branches substitute for subsidiaries belonging to the same banking } \\
\text { group) and competition channel (foreign branches substitute for any } \\
\text { banks contracting credit). No evidence for capital markets leakage is } \\
\text { found. }\end{array}$ \\
\hline BoE No. 486 & $\begin{array}{l}\text { The impact of capital requirements on bank } \\
\text { lending, 2014, Jonathan Bridges, David Gregory, } \\
\text { Mette Nielsen, Silvia Pezzini, Amar Radia and } \\
\text { Marco Spaltro }\end{array}$ & $\begin{array}{l}\text { A } 1 \% \text { rise in capital requirements reduces mortgage, commercial real } \\
\text { estate and other PNFC lending by } 0.94 \%, 8.07 \% \text { and } 3.86 \% \text {, } \\
\text { respectively. }\end{array}$ \\
\hline BoE No. 494 & $\begin{array}{l}\text { Estimating the impact of changes in aggregate } \\
\text { bank capital requirements during an upswing, } \\
\text { 2014, Joseph Noss and Priscilla Toffano }\end{array}$ & $\begin{array}{l}\text { A } 15 \text { bps rise in capital requirements leads to a } 1.4 \% \text { lending } \\
\text { contraction after four years. No statistically significant impact on real } \\
\text { GDP is found. }\end{array}$ \\
\hline BoE No. 497 & $\begin{array}{l}\text { The international transmission of bank capital } \\
\text { requirements: evidence from the United } \\
\text { Kingdom, 2014, Shekhar Aiyar, Charles } \\
\text { Calomiris, John Hooley, Yevgeniya Korniyenko } \\
\text { and Tomasz Wieladek }\end{array}$ & $\begin{array}{l}\text { A one percent rise in capital requirements reduces cross-border } \\
\text { interbank lending by } 5.4 \% \text {. Core business destination countries are not } \\
\text { affected. }\end{array}$ \\
\hline BoE No. 508 & $\begin{array}{l}\text { How does credit supply respond to monetary } \\
\text { policy and bank minimum capital requirements?, } \\
\text { 2014, Shekhar Aiyar, Charles Calomiris and } \\
\text { Tomasz Wieladek }\end{array}$ & $\begin{array}{l}\text { Monetary policy only affects small banks via the bank lending } \\
\text { channel, while changes to capital requirements affect all banks. No } \\
\text { evidence for interaction among these instruments is found. }\end{array}$ \\
\hline
\end{tabular}




\begin{tabular}{|c|c|c|}
\hline BoE No. 524 & $\begin{array}{l}\text { On a tight leash: does bank organisational } \\
\text { structure matter for macroprudential spillovers?, } \\
\text { 2015, Piotr Danisewicz, Dennis Reinhardt and } \\
\text { Rhiannon Sowerbutts }\end{array}$ & $\begin{array}{l}\text { Foreign branches transmit capital regulations in their home country to } \\
\text { a greater extent than foreign subsidiaries of the same banking group. }\end{array}$ \\
\hline BoE No. 536 & $\begin{array}{l}\text { The impact of liquidity regulation on banks, } \\
\text { 2015, Ryan N Banerjee and Hitoshi Mio }\end{array}$ & $\begin{array}{l}\text { Banks reduce their reliance on wholesale funding and financial loans } \\
\text { in response to the introduction of individual liquidity guidance } \\
\text { regulation. But they do not find evidence that the tightening of } \\
\text { liquidity regulation caused banks to shrink their balance sheets, nor } \\
\text { reduce the amount of lending to the non-financial sector. }\end{array}$ \\
\hline BoE No. 546 & $\begin{array}{l}\text { Regulatory arbitrage in action: evidence from } \\
\text { banking flows and macroprudential policy, 2015, } \\
\text { Dennis Reinhardt and Rhiannon Sowerbutts }\end{array}$ & $\begin{array}{l}\text { Foreign banks expand lending to the domestic non-bank sector when } \\
\text { domestic macroprudential capital policies are tightened. This does not } \\
\text { happen when (i) capital regulations also apply to foreign banks and (ii) } \\
\text { for lending standards regulations which usually apply to all lending in } \\
\text { a country. }\end{array}$ \\
\hline BoE No. 572 & $\begin{array}{l}\text { Capital requirements, risk shifting and the } \\
\text { mortgage market, 2015, Arzu Uluc and Tomasz } \\
\text { Wieladek }\end{array}$ & $\begin{array}{l}\text { A } 1 \% \text { rise in the capital requirement leads the affected bank to cut } \\
\text { back mortgage loan size by about } 5.4 \% \text {. Consistent with risk shifting, } \\
\text { loans to the riskiest borrowers are not affected. }\end{array}$ \\
\hline BoE No. 573 & $\begin{array}{l}\text { The real effects of capital requirements and } \\
\text { monetary policy: evidence from the United } \\
\text { Kingdom, 2015, Filippo De Marco and Tomasz } \\
\text { Wieladek }\end{array}$ & $\begin{array}{l}\text { SMEs contract asset growth by about } 3.5 \%-6.9 \% \text { following a } 1 \% \text { rise } \\
\text { in the capital requirement of their main relationship bank. Monetary } \\
\text { policy only affects the asset growth of these SMEs which borrow from } \\
\text { small banks. The effects of monetary policy and capital requirements } \\
\text { reinforce each other for SMEs that borrow from small banks. }\end{array}$ \\
\hline BoE No. 593 & $\begin{array}{l}\text { What determines how banks respond to changes } \\
\text { in capital requirements?, 2016, Saleem Bahaj, } \\
\text { Jonathan Bridges, Frederic Malherbe and Cian } \\
\text { O'Neill }\end{array}$ & $\begin{array}{l}\text { Bank lending is less affected by changes in capital requirements when } \\
\text { lending prospects are good and legacy assets are healthy. }\end{array}$ \\
\hline BoE No. 595 & $\begin{array}{l}\text { Cross-border regulatory spillovers: How much? } \\
\text { How important? What sectors? Lessons from the } \\
\text { United Kingdom, 2016, Robert Hills, Dennis } \\
\text { Reinhardt, Rhiannon Sowerbutts and Tomasz } \\
\text { Wieladek }\end{array}$ & $\begin{array}{l}\text { Macroprudential regulation in foreign countries does not affect UK } \\
\text { domestic lending, consistent with the idea that the UK is a core } \\
\text { business destination for most banks. More granular results show that } \\
\text { foreign affiliates increase lending to UK households once there is a } \\
\text { tightening in LTV regulation in their home countries. }\end{array}$ \\
\hline
\end{tabular}




\section{Appendix B: Data, Statistics, and Additional Results}

\section{Appendix Table B1 - Variable Definitions and Sources}

\begin{tabular}{|c|c|c|}
\hline Variable & Definition & Source \\
\hline $\begin{array}{l}\text { Cross-border bank } \\
\text { lending growth }\end{array}$ & $\begin{array}{l}\text { Percent change in cross-border lending to banks } \\
\text { plus non-banks [CC15], only banks [CC15A] or } \\
\text { only non-banks [CC15B]. }\end{array}$ & $\begin{array}{l}\text { Bank of England CC } \\
\text { forms. }\end{array}$ \\
\hline $\begin{array}{l}\text { Capital } \\
\text { Requirements } \\
\text { (Changes) }\end{array}$ & $\begin{array}{l}\text { FSA/PRA-set minimum ratio for Pillar } 1 \text { plus } \\
\text { Pillar } 2 \text { capital-to-risk weighted assets (RWA). } \\
\text { [NHD500/NHD510 for BSD3 and 108A/(12.5* } \\
\text { 70A) for FSA3. }\end{array}$ & $\begin{array}{l}\text { Bank of England BSD3 } \\
\text { form for data up to } 2008 \\
\text { Q1. FSA3 form thereafter. }\end{array}$ \\
\hline Fracdummy & $\begin{array}{l}\text { Fraction of bank lending to UK households and } \\
\text { PNFCs in total bank lending. }\end{array}$ & $\begin{array}{l}\text { Bank of England BT, AL } \\
\text { and CC forms. }\end{array}$ \\
\hline QE & $\begin{array}{l}\text { Changes in the size of the Bank of England's } \\
\text { Quantitative Easing programme scaled by UK } \\
\text { nominal GDP as of } 2009 \text { Q1 (expressed in \%). }\end{array}$ & $\begin{array}{l}\text { Bank of England MPC } \\
\text { minutes. }\end{array}$ \\
\hline $\begin{array}{l}\text { Commitment } \\
\text { Share }\end{array}$ & $\begin{array}{l}\text { Commitment ratio: Ratio of total commitments } \\
\text { divided by total assets. [BT43/BT40] }\end{array}$ & Bank of England BT forms \\
\hline Liquid Asset Share & $\begin{array}{l}\text { Holdings of liquid assets (cash, market loans, } \\
\text { British government stocks) scaled by non-equity } \\
\text { liabilities. [(BT21+BT23+BT32D)/(BT20-BT19)]. }\end{array}$ & Bank of England BT forms \\
\hline Deposit Share & $\begin{array}{l}\text { Deposit Share. Fraction of the banking } \\
\text { organization's balance sheet financed with core } \\
\text { deposits }[(\mathrm{BT} 2 \mathrm{H}+\mathrm{BT} 3 \mathrm{H}) /(\mathrm{BT} 20-\mathrm{BT} 19)] \text {. }\end{array}$ & Bank of England BT forms \\
\hline Writeoffs & $\begin{array}{l}\text { Writeoffs (Changes) [80T from BSD3 and 32J } \\
\text { from FSA15]. }\end{array}$ & $\begin{array}{l}\text { Bank of England BSD3 } \\
\text { forms for data up to } 2008 \\
\text { Q1 and FSA15 forms for } \\
\text { data thereafter. }\end{array}$ \\
\hline Bank size & $\begin{array}{l}\text { Bank size: The log of a bank's total assets in levels } \\
\text { ( } £ 1000 \text { s), deflated by CPI inflation [BT40]. }\end{array}$ & Bank of England BT forms \\
\hline $\begin{array}{l}\text { Exposure- } \\
\text { weighted GDP } \\
\text { forecast }\end{array}$ & $\begin{array}{l}\text { Exposure weighted GDP forecast is defined as } \\
\text { forecasted real GDP growth averaged over the } \\
\text { following two years minus the same forecast last } \\
\text { year. }\end{array}$ & IMF WEO database. \\
\hline GDP Growth & Annual Real GDP Growth in \%. (NGDP_RPCH). & IMF WEO database. \\
\hline Returns & $\begin{array}{l}\text { Domestic equity returns: MSCI total returns } \\
\text { index (end period). Quarterly \% returns. }\end{array}$ & MSCI from Datastream. \\
\hline CDS Spread. & 5-year sovereign CDS spreads. & Bloomberg. \\
\hline $\begin{array}{l}\text { Institutional } \\
\text { Quality }\end{array}$ & $\begin{array}{l}\text { Country-specific estimates of the strength of the } \\
\text { rule of law, ranging from }-2.5 \text { to }+2.5 \text { with } \\
\text { positive values indicating stronger institutions. }\end{array}$ & $\begin{array}{l}\text { World Bank World } \\
\text { Governance Indicators. }\end{array}$ \\
\hline $\begin{array}{l}\text { Capital Regulation, } \\
\text { LTV regulations, } \\
\text { Local Reserve } \\
\text { Requirements }\end{array}$ & $\begin{array}{l}\text { Quarterly indices of the intensity of } \\
\text { macroprudential policy regulation proxied by } \\
\text { cumulated tightening minus cumulated } \\
\text { loosening actions (2000-2014). }\end{array}$ & Cerutti et al. (2015). \\
\hline Capital Controls & $\begin{array}{l}\text { Overall restrictions index }(\mathrm{ka}) \text { ranging from } 0 \text { to } \\
1 \text {, with } 1 \text { being more restrictive. }\end{array}$ & Fernández et al. (2015) \\
\hline
\end{tabular}


Appendix Table B2: Summary Statistics

\begin{tabular}{|c|c|c|c|c|c|}
\hline Variable & Median & Mean & $\mathrm{p} 25$ & p75 & Obs. \\
\hline External bank lending growth & -0.005 & -0.036 & -0.158 & 0.096 & 47421 \\
\hline External bank-to-bank lending growth & -0.039 & -0.138 & -0.415 & 0.086 & 31791 \\
\hline External bank-to-non-bank lending growth & -0.005 & -0.036 & -0.127 & 0.072 & 41839 \\
\hline Fraction & 0.087 & 0.153 & 0.007 & 0.236 & 47421 \\
\hline Liquid Asset Share & 0.272 & 0.359 & 0.172 & 0.529 & 47421 \\
\hline Bank Size (Log, deflated) & 16.445 & 16.712 & 15.034 & 18.46 & 47421 \\
\hline Commitment Share & 0.506 & 0.517 & 0.33 & 0.691 & 47421 \\
\hline Deposit Share & 0.204 & 0.294 & 0.044 & 0.506 & 47421 \\
\hline Writeoffs & 0.004 & 0.013 & 0 & 0.015 & 47421 \\
\hline GDP Growth & 2.786 & 2.999 & 1.205 & 4.652 & 40143 \\
\hline CDS Spread & 40.798 & 118.167 & 6.078 & 129.882 & 26057 \\
\hline Returns & 3.541 & 2.852 & -4.482 & 10.099 & 31385 \\
\hline Institutional Quality & 1.294 & 1.025 & 0.531 & 1.732 & 42529 \\
\hline Capital Controls & 0.125 & 0.213 & 0.05 & 0.3 & 35078 \\
\hline Capital Regulation & 0 & 0.277 & 0 & 0 & 31539 \\
\hline LTV Regulation & 0 & 0.574 & 0 & 1 & 11529 \\
\hline \multirow[t]{2}{*}{ Reserve Requirements (Local) } & 0 & -0.431 & -1 & 0 & 32963 \\
\hline & & & $\min$ & $\max$ & \\
\hline Quantiative Easing & 3.6 & 3.834 & 1.8 & 5.339 & 7 \\
\hline
\end{tabular}

Note: The data are discussed in Section 2.3. Variables are discussed in Sections 3.1 and 4.3. Fraction refers to the fraction of domestic non-financial lending to total lending. Summary statistics for Quantitative Easing refer to the 7 quarters in which the size of the asset purchase programme was altered (see Figure $4 \mathrm{~b}$ ).

\section{Appendix Table B3: Tightening vs. Loosening of Capital Regulations}

Total External Lending Growth

(1)

(2)

pre-GFC 1997-2007 post-GFC 2010-2015

\begin{tabular}{|c|c|c|c|}
\hline \multirow[t]{2}{*}{$\Delta$ Capital Requirements Tightening } & & $-6.177 * * *$ & $-4.794 * * *$ \\
\hline & $p$-val & 0.00669 & 0.00560 \\
\hline \multirow[t]{2}{*}{$\Delta$ Capital Requirements Loosening } & & -2.697 & -0.959 \\
\hline & $p$-val & 0.106 & 0.491 \\
\hline
\end{tabular}

Test if Tightening diff. from Loosening ( $p$-val)

0.207

0.053

\begin{tabular}{lcc}
\hline Observations & 41,792 & 17,186 \\
Adj. R-squared & 0.0468 & 0.0284 \\
Bank Fixed Effects & YES & YES \\
Country-Time-Effects & YES & YES \\
Cluster & Bank-Time & Bank-Time \\
\hline
\end{tabular}

Note: The table presents the estimated parameter values from fixed effects panel regressions. The dependent variable is the quarterly percentage change in external bank lending. In column (1), the sample period is 1997Q1 to 2007Q4. In column (2), the sample period is 2010Q1 to 2015Q1. The data are discussed in Section 2.3. Variables are discussed in Section 3.1 and Appendix B. Standard errors are clustered at the bank-time level. ${ }^{* * *}$ is significant at the $1 \%$ level, ${ }^{* *}$ at the $5 \%$ level and ${ }^{*}$ at the $10 \%$ level. 


\section{Appendix Table B4: Controlling for Liquidity Regulations}

\begin{tabular}{|c|c|c|c|}
\hline & \multirow{2}{*}{$\begin{array}{c}\text { (1) } \\
\text { Total External } \\
\text { Lending }\end{array}$} & \multirow{2}{*}{$\begin{array}{c}\text { (2) } \\
\text { Bank-to-Bank } \\
\text { Lending }\end{array}$} & \multirow{2}{*}{$\begin{array}{c}\text { (3) } \\
\begin{array}{c}\text { Bank-to-Nonbank } \\
\text { Lending }\end{array} \\
\end{array}$} \\
\hline & & & \\
\hline$\Delta$ Capital Requirements & -1.804 & 4.626 & -1.571 \\
\hline$p$-val & 0.354 & 0.118 & 0.445 \\
\hline$\Delta$ Capital Requirements * FLS 1 & 3.735 & 0.991 & 1.135 \\
\hline p-val & 0.197 & 0.826 & 0.726 \\
\hline$\Delta$ Capital Requirements * Fraction 1 & -0.754 & $-4.974 *$ & -1.620 \\
\hline p-val & 0.658 & 0.0638 & 0.444 \\
\hline$\Delta$ Capital Requirements * FLS $1 *$ Fraction 1 & $-6.141 * *$ & $-6.900 * *$ & -4.798 \\
\hline p-val & 0.0160 & 0.0113 & 0.121 \\
\hline$\Delta$ Capital Requirements * FLS 2 & $9.668^{*}$ & $12.13^{*}$ & 4.648 \\
\hline p-val & 0.0723 & 0.0991 & 0.402 \\
\hline$\Delta$ Capital Requirements * Fraction 2 & -0.290 & 2.088 & 2.358 \\
\hline p-val & 0.829 & 0.343 & 0.164 \\
\hline$\Delta$ Capital Requirements * FLS $2 *$ Fraction 2 & -1.670 & -3.024 & -3.319 \\
\hline $\mathrm{p}$-val & 0.444 & 0.262 & 0.181 \\
\hline$\Delta$ Capital Requirements * $\mathrm{QE}$ & -0.764 & -0.999 & $-1.487^{* *}$ \\
\hline$p$-val & 0.173 & 0.206 & 0.0205 \\
\hline$\Delta$ Liquidity Regulation (ILG) & $-0.0647 * *$ & -0.0242 & $-0.0539 *$ \\
\hline$p$-val & 0.0360 & 0.660 & 0.0670 \\
\hline Observations & 47,421 & 29,317 & 43,051 \\
\hline Adjusted R-squared & 0.0359 & 0.0645 & 0.0432 \\
\hline Bank Controls & YES & YES & YES \\
\hline Bank Fixed Effects & YES & YES & YES \\
\hline Country-Time-Effects & YES & YES & YES \\
\hline Cluster & Bank-Time & Bank-Time & Bank-Time \\
\hline
\end{tabular}

Note: The table presents the estimated parameter values from fixed effects panel regressions. In column (1), the dependent variable is the quarterly percentage change in external bank lending; in column (2), the quarterly percentage change in external bank lending to other banks; in column (3), the quarterly percentage change in external bank lending to non-banks. $\Delta$ ILG is a dummy that is equal to 1 if bankspecific Individual Liquidity Guidance (ILG) requirements were introduced or increased, 0 otherwise (see section 4.4 for details). The data are discussed in Section 2.3. Variables are discussed in Section 3.1 and Appendix B. Standard errors are clustered at the bank-time level. ${ }^{* * *}$ is significant at the $1 \%$ level, ${ }^{* *}$ at the $5 \%$ level, and ${ }^{*}$ at the $10 \%$ level. The sample period is $1997 \mathrm{Q} 1$ to $2015 \mathrm{Q} 1$ 


\section{Appendix C: Exogeneity of $\Delta K R_{j, t}$}

An important assumption in our regression framework is the exogeneity of changes in capital requirements with respect to bank balance sheet variables. Given the importance of this assumption to our framework, it needs to be explored more formally. In order to do so, we test if bank balance sheet variables that supervisors had access to at the time of the regulatory decision can statistically predict regulatory changes. If this is the case and the balance sheet variables can explain a high fraction of the variation in capital requirements, then our initial assertion would have been invalid. If all relevant balance sheet variables have been included in the model predicting changes in capital requirements, however, then the residual will reflect any capital requirement changes that reflect non-balance sheet risk. We can therefore use the residual from a model using balance sheet variables to predict changes in capital requirements to verify if the results change when we use these "non-balance sheet based" capital requirement changes in our model.

We have collected 31 such variables. These are mainly taken from the FSA003 form, the reporting form that regulators had access to when making regulatory decisions. This form also contains information on several measures of balance sheet risk, such as interest rate, counterparty or foreign exchange rate risk. We also incorporate additional balance sheet information that may be relevant, but was not on this form, such as the growth in lending to different domestic and external sectors, liquid assets and the deposit ratio. This is a fairly complete and exhaustive list of the information available to the regulators when making their assessments. Of course, supervisors could also have considered additional information and less tangible measures, but this extensive set of variables should allow us to create a fairly exogenous measure of changes in capital regulations.

We then explore if changes in capital requirements can be predicted by any of these variables with the following regression framework:

$$
\Delta K R_{i}=\beta X_{i}+\varepsilon_{i}
$$

where $\Delta K R_{i}$ is the non-zero change in capital requirements for bank $i$ and $X_{i}$ is the matrix of exogenous variables that helps to predict this particular instance of $\Delta K R_{i}$. Under the assumption that the information set contained in the vector of predictors $X_{i}$, the residual $\left(\varepsilon_{i}\right)$ will reflect capital requirement changes due to non-balance sheet risk, which are exogenous with respect to balance sheet items. There is also uncertainty about whether these predictors affect the supervisory decisions contemporaneously or with a lag. For these reasons, we use growth rates that are contemporaneous, lagged, or taken with respect to the same value a year ago.

We adopt a two-step approach to isolate the most important predictors of changes in capital requirements among these 93 potential candidate predictors. First, we regress each individual predictor against the change in the capital requirement with a single regression. The results are reported in Appendix Table C1. We then retain those predictors which are statistically significant. This allows us to reduce the universe of candidate predictors to about 18. However, we have little information on whether supervisors looked at these indicators together or individually to form their judgement about a capital requirement change. With the 18 relevant variables, there are over 262,144 regression models that could be explored for this purpose. We therefore follow the Bayesian Modelling Approach (BMA) proposed in the economic growth literature and discussed in more detail below to explore all of these possible model 
combinations. ${ }^{42}$ Appendix Table C2 presents the results from this exercise. This suggests that variables such as domestic real sector growth and financial operating charges are strong predictors of tightening in Pillar 2 capital requirements.

Finally, we use all of the important predictors from this BMA exercise in multiple regressions to derive our measure of exogenous changes in capital requirements. Recognising the second step nature of the BMA output, we include all predictors that have a posterior inclusion probability ( $\mathrm{PiP}$ ) of either 40 or 20 percent in regression equations (1) and (2). Results are reported in Appendix Table C3. Both regression equations include external lending growth, which is not statistically significant in either case. We only retain predictors that entered as significant in both of these regression equations in regression equation 3 . We refer to regression equations two and three in Table C3 as models 1 and 2 for the remainder of the paper. Each of the resulting balance sheet variables used to predict changes in capital requirements are highly statistically significant in both of these regression models. Therefore, balance sheet characteristics do predict changes in capital requirements. According to the $R^{2}$, in these equations, however, they can only explain $25 \%$ to $30 \%$ of the variation in capital requirements. Assuming that we included all relevant balance sheet variables, this means that between $70 \%$ and $75 \%$ of the variation in capital requirement changes is due to non-balance sheet risk. This is consistent with the regulatory approach during this period; credit and market risk would typically be accounted for in the Pillar 1 capital requirement. The Pillar 2 add on, which is the focus of this paper, is primarily used as a discretionary supplement to account for other risks.

Balance sheets, however, only summarize the state of a given bank in a backward looking way. In practice supervisors probably also took expected portfolio performance into account. To provide a proxy for this, we weight changes in GDP forecasts based on the countries to which a bank is exposed. This variable is an indicator of changes in the future economic outlook of these countries that a given bank lends to, and hence an important indicator of future international portfolio performance. We include this in column (4) of Table C3. The coefficient has the expected negative sign, implying that better expected international portfolio performance is associated with lower capital requirements.

Given that the residuals of these regressions are, by definition, orthogonal to the balance sheet characteristics, we can use them as measures of changes in non-balance sheet risk capital requirements. Using the residuals obtained from model (1) and model (2) and/or including the forward-looking measures in column (4) to address any endogeneity in capital requirements does not make a significant difference to our key results.

\section{Details on Bayesian Model Averaging}

This section provides more detail on our implementation of Bayesian Model Averaging. We have up to $18(k)$ possible predictors of the change in capital requirements, but only some of these predictors seem to matter the most for regulatory decisions. The economic growth literature has proposed Bayesian Model Averaging to objectively determine which variable has the highest explanatory power. We follow this approach here to select the best predictors of changes in capital requirements based on their posterior inclusion probabilities.

The idea underlying Bayesian Model Averaging is to consider the results for all the models which include all possible combinations of the regressors and average them. The weights in the averaging are given by the posterior model probabilities $p(M \mid y)$ where $M$ is the model and

${ }^{42}$ See Doppelhofer, Miller and Sala-i-Martin (2004). 
$y$ is the data. In order to compute the posterior model probabilities by means of Bayes rule, two elements are required. First, we need the posterior distribution of the parameters in each model $M$, which is used to derive the marginal likelihood $p(y \mid M)$. Second, we need to specify the prior distribution of the models $p(M)$. With marginal likelihood and model prior distributions at hand, the model posterior probabilities can be derived as:

$$
p(M \mid y) \propto p(y \mid M) p(M) .
$$

As to the setup of the priors, we follow Fernandez, Ley and Steel (2001). In particular, for each model, we compute the posterior probability distribution of the parameters by assuming an uninformative prior on the variance of the residuals and on the intercept. For the remaining regression coefficients we use the g-prior of Zellner (1986), setting $g=\frac{1}{\max \left(N, k^{2}\right)}$. We set a uniform prior for the distribution of the models. ${ }^{43}$ Since we only have up to 8,388,608 models, we follow Magnus, Powel and Pruefer (2010) and evaluate each one of them to obtain the exact likelihood, without having to rely on MCMC methods for approximation. High posterior inclusion probabilities indicate that, irrespective of which other explanatory variables are included, the regressor has a strong explanatory power. We argue that this is therefore an efficient and objective way to select the best predictors of the changes in capital requirements.

\footnotetext{
${ }^{43}$ In practical terms, Bayesian Model Averaging is implemented with the STATA BMA function documented in De Luca and Magnus (2011)
} 


\section{Appendix Table C1: Determinants of Capital Requirements: Single Regressions}

\begin{tabular}{|c|c|c|c|}
\hline & & quirement $\mathrm{Ti}$ & ening \\
\hline & (1) & (2) & (3) \\
\hline & Lagged Growth & Annual Growth & Current Growth \\
\hline Financial and Operating Income & 0.0168 & $0.238 * * *$ & -0.0106 \\
\hline & $(0.0214)$ & $(0.0895)$ & $(0.0271)$ \\
\hline Interest income & 0.0319 & $0.338^{* *}$ & -0.00886 \\
\hline & $(0.0326)$ & $(0.170)$ & $(0.0447)$ \\
\hline Fee and commission income & 0.0228 & $0.593^{* *}$ & -0.0485 \\
\hline & $(0.0474)$ & $(0.292)$ & $(0.0783)$ \\
\hline Trading income/losses & 0.0371 & -0.272 & -0.226 \\
\hline & (0.128) & $(0.228)$ & (0.169) \\
\hline Trading income/losses on trading investments & 0.0813 & 0.315 & 0.0719 \\
\hline & $(0.0914)$ & $(0.476)$ & (0.144) \\
\hline Trading income/losses on foreign exchange & -0.108 & -0.866 & -0.278 \\
\hline & $(0.201)$ & (1.024) & $(0.303)$ \\
\hline Realised gains/losses on financial assets \& liabilities & -0.0363 & $3.301 * * *$ & 0.664 \\
\hline & $(0.273)$ & $(1.021)$ & $(0.837)$ \\
\hline Dividend income & -0.138 & 0.0151 & 0.170 \\
\hline & $(0.277)$ & $(0.672)$ & $(0.235)$ \\
\hline Other operating income & -0.0956 & $0.795 * * *$ & $0.558^{* *}$ \\
\hline & $(0.271)$ & $(0.159)$ & $(0.236)$ \\
\hline Financial \& Operating Charges & 0.0358 & $0.466 * * *$ & 0.00455 \\
\hline & (0.0407) & $(0.152)$ & $(0.0591)$ \\
\hline Other costs & 0.00737 & $0.376^{* * *}$ & 0.0125 \\
\hline & $(0.0266)$ & $(0.119)$ & $(0.0362)$ \\
\hline (of which) Impairment/Provisions & -0.0278 & $0.861^{* * *}$ & $0.204^{*}$ \\
\hline & (0.0796) & $(0.271)$ & $(0.123)$ \\
\hline Net profit (loss) & 0.0305 & -0.154 & -0.0725 \\
\hline & $(0.0505)$ & $(0.337)$ & $(0.0636)$ \\
\hline Write-offs & 0.0886 & $-0.161^{*}$ & -0.00731 \\
\hline & $(0.183)$ & $(0.0961)$ & $(0.202)$ \\
\hline Counterparty risk capital component & 0.391 & -0.436 & -1.352 \\
\hline & (0.649) & (1.984) & $(1.006)$ \\
\hline Interest Rate Risk (PRR, stan. approach) & -0.214 & 0.602 & 0.00829 \\
\hline & $(0.411)$ & $(1.582)$ & (1.048) \\
\hline Foreign currency Risk (PRR, stan. approach) & $2.019 * * *$ & 1.679 & -0.895 \\
\hline & $(0.615)$ & (2.672) & $(0.945)$ \\
\hline Position, FX and commodity risk (internal models) & $-0.676 *$ & 0.0545 & $0.837^{*}$ \\
\hline & (0.393) & $(0.813)$ & (0.438) \\
\hline Pillar 1 credit risk capital component & $0.188^{*}$ & 0.484 & 0.197 \\
\hline & (0.108) & $(0.428)$ & $(0.222)$ \\
\hline Pillar 1 market risk capital component & -0.175 & 0.397 & 0.0776 \\
\hline & (0.226) & (0.949) & $(0.422)$ \\
\hline Deposit Share & 0.00454 & 0.0131 & 0.00359 \\
\hline & (0.0498) & (0.0178) & $(0.0384)$ \\
\hline Liquid Asset Share & 0.00758 & -0.00147 & 0.0175 \\
\hline & $(0.00825)$ & $(0.00701)$ & $(0.0120)$ \\
\hline Commitment Share & -0.0106 & 0.00931 & 0.0178 \\
\hline & $(0.0246)$ & $(0.00881)$ & $(0.0282)$ \\
\hline Leverage Ratio & 0.0283 & 0.0126 & -0.00162 \\
\hline & $(0.0453)$ & $(0.0232)$ & $(0.0566)$ \\
\hline External bank lending growth & 0.00910 & $0.0195^{*}$ & 0.00629 \\
\hline & $(0.00648)$ & $(0.00989)$ & $(0.00617)$ \\
\hline External bank-to-bank lending growth & $-1.46 e-05$ & $0.0120^{*}$ & 0.00659 \\
\hline & $(0.00296)$ & $(0.00663)$ & (0.00419) \\
\hline External bank-to-non-bank lending growth & 0.00673 & 0.00890 & -0.00374 \\
\hline & $(0.00609)$ & $(0.0102)$ & $(0.00824)$ \\
\hline Total balance sheet growth & 0.0104 & 0.0253 & 0.00738 \\
\hline & $(0.0111)$ & (0.0187) & $(0.0110)$ \\
\hline Domestic real sector lending growth & -0.00513 & $0.0122^{*}$ & $0.0160^{*}$ \\
\hline & $(0.00607)$ & $(0.00644)$ & $(0.00814)$ \\
\hline Domestic financial lending growth & 0.000716 & 0.00362 & 0.00669 \\
\hline & $(0.00527)$ & $(0.00620)$ & $(0.00423)$ \\
\hline Domestic interbank lending growth & 0.00285 & 0.00326 & 0.00331 \\
\hline & $(0.00342)$ & $(0.00493)$ & $(0.00320)$ \\
\hline
\end{tabular}

Note: The table presents the estimated parameter values cross-sectional regressions of capital requirement tightening on regulatory and balance sheet variables. Column (1) uses the lagged change of the respective variables scaled risk weighted assets in the quarter before. Column (2) uses changes of respective variables scaled risk weighted assets in the quarter before averaged over 1 year and lagged by one quarter. Column (3) uses the current change of the respective variables scaled risk weighted assets of the quarter before. See Section 4.5 and this appendix for further information on how we obtain the exogenous component of capital requirement changes. Robust standard errors are given in parenthesis. ${ }^{* *}$ is significant at the $1 \%$ level, ${ }^{* *}$ at the $5 \%$ level, and ${ }^{*}$ at the $10 \%$ level. 
Appendix Table C2: Determinants of Capital Requirement Tightening: BMA

\begin{tabular}{|c|c|c|c|}
\hline & & (1) & (2) \\
\hline Variable & Transformation & Coefficient & PIP \\
\hline \multirow[t]{2}{*}{ Constant } & & $0.00934 * * *$ & \\
\hline & & $(0.000939)$ & \\
\hline \multirow[t]{2}{*}{ Financial and Operating Income } & Annual Growth & -0.00256 & 0.08 \\
\hline & & $(0.0540)$ & \\
\hline \multirow[t]{2}{*}{ Interest income } & Annual Growth & -0.0818 & 0.22 \\
\hline & & $(0.230)$ & \\
\hline \multirow[t]{2}{*}{ Fee and commission income } & Annual Growth & -0.00573 & 0.06 \\
\hline & & $(0.0913)$ & \\
\hline \multirow[t]{2}{*}{ Realised gains/losses on financial assets $\&$ liabilitie } & Annual Growth & 0.943 & 0.34 \\
\hline & & $(1.523)$ & \\
\hline \multirow[t]{2}{*}{ Other operating income } & Annual Growth & 0.0152 & 0.09 \\
\hline & & $(0.169)$ & \\
\hline \multirow[t]{2}{*}{ Other operating income } & Current Growth & 0.468 & 0.74 \\
\hline & & $(0.339)$ & \\
\hline \multirow[t]{2}{*}{ Financial \& Operating Charges } & Annual Growth & $0.541^{*}$ & 0.95 \\
\hline & & $(0.278)$ & \\
\hline \multirow[t]{2}{*}{ Other costs } & Annual Growth & 0.00913 & 0.08 \\
\hline & & $(0.0607)$ & \\
\hline \multirow[t]{2}{*}{ Impairment/Provisions } & Annual Growth & 0.0461 & 0.12 \\
\hline & & $(0.163)$ & \\
\hline \multirow[t]{2}{*}{ Impairment/Provisions } & Current Growth & -0.000106 & 0.05 \\
\hline & & $(0.0277)$ & \\
\hline \multirow[t]{2}{*}{ Write-offs } & Annual Growth & 0.00155 & 0.05 \\
\hline & & $(0.0662)$ & \\
\hline \multirow[t]{2}{*}{ Foreign currency Risk (PRR, stan. approach) } & Lagged Growth & 0.0836 & 0.07 \\
\hline & & $(0.495)$ & \\
\hline \multirow[t]{2}{*}{ Position, FX and commodity risk (internal models) } & Lagged Growth & -0.0473 & 0.08 \\
\hline & & $(0.221)$ & \\
\hline \multirow[t]{2}{*}{ Position, FX and commodity risk (internal models) } & Current Growth & 0.0297 & 0.07 \\
\hline & & $(0.193)$ & \\
\hline \multirow[t]{2}{*}{ Pillar 1 credit risk capital component } & Lagged Growth & 0.00327 & 0.05 \\
\hline & & $(0.0376)$ & \\
\hline \multirow[t]{2}{*}{ External bank lending growth } & Annual Growth & 0.000758 & 0.08 \\
\hline & & $(0.00400)$ & \\
\hline \multirow[t]{2}{*}{ External bank-to-bank lending growth } & Annual Growth & 0.000167 & 0.06 \\
\hline & & $(0.00200)$ & \\
\hline \multirow[t]{2}{*}{ Domestic real sector lending growth } & Annual Growth & 0.000125 & 0.05 \\
\hline & & $(0.00239)$ & \\
\hline \multirow[t]{2}{*}{ Domestic real sector lending growth } & Current Growth & $0.0150 * * *$ & 0.96 \\
\hline & & $(0.00520)$ & \\
\hline
\end{tabular}




\section{Appendix Table C3: Determinants of Capital Requirement Tightening: Keeping Important Predictors}

\begin{tabular}{|c|c|c|c|c|}
\hline & (1) & (2) & (3) & (4) \\
\hline \multirow[t]{2}{*}{ Other operating income (Current Growth) } & $0.596 * * *$ & $0.664 * * *$ & $0.617^{* * *}$ & $0.507^{* * *}$ \\
\hline & (0.163) & $(0.178)$ & $(0.163)$ & $(0.180)$ \\
\hline \multirow[t]{2}{*}{ Financial \& Operating Charges (Annual Growth) } & $0.461^{* * *}$ & $0.818^{* * *}$ & $0.487^{* * *}$ & $0.447 * * *$ \\
\hline & $(0.118)$ & $(0.287)$ & $(0.115)$ & $(0.117)$ \\
\hline \multirow[t]{2}{*}{ Domestic real sector lending growth (Current Growth) } & $0.0166 * * *$ & $0.0158^{* *}$ & $0.0162^{* * *}$ & $0.0158^{* *}$ \\
\hline & $(0.00598)$ & $(0.00619)$ & $(0.00607)$ & $(0.00637)$ \\
\hline \multirow[t]{2}{*}{ External bank lending growth (Annual Growth) } & 0.00817 & 0.00856 & & \\
\hline & $(0.00899)$ & $(0.00900)$ & & \\
\hline \multirow[t]{2}{*}{ Realised gains/losses on financial assets \& liabilities (Annual Growth) } & & 2.116 & & \\
\hline & & $(1.287)$ & & \\
\hline \multirow[t]{2}{*}{ Interest income (Annual Growth) } & & -0.356 & & \\
\hline & & $(0.243)$ & & \\
\hline \multirow[t]{2}{*}{ Exposure weighted GDP forecast } & & & & $-0.262^{* *}$ \\
\hline & & & & (0.104) \\
\hline \multirow[t]{3}{*}{ Constant } & $0.00943^{* * *}$ & $0.00910^{* * *}$ & $0.00930 * * *$ & $0.00916 * * *$ \\
\hline & $(0.000884)$ & $(0.000879)$ & $(0.000876)$ & $(0.000865)$ \\
\hline & & Model 1 & Model 2 & Model $2+$ Fcast \\
\hline Observations & 126 & 126 & 126 & 126 \\
\hline R-squared & 0.259 & 0.299 & 0.255 & 0.283 \\
\hline Adjusted R2 & 0.235 & 0.263 & 0.237 & 0.259 \\
\hline
\end{tabular}

Note: The table presents the estimated parameter values cross-sectional regressions of capital requirement tightening on regulatory and balance sheet variables. Column (1) keeps variables which have in Table C2 a posterior inclusion probability ( $\mathrm{PiP}$ ) of 40 percent in addition to external bank lending growth. Column (2) includes variables with a PiP of 20 percent. Column (3) keeps only the significant variables. Column (4) includes a measure of forward-looking growth surprises, namely, the forecasted real GDP growth averaged over the following two years minus the same forecast last year from the IMF's WEO database. See this Appendix and Section 4.5 for further information on how we obtain the exogenous component of capital requirement changes. Robust standard errors are given in parenthesis. ${ }^{* * *}$ is significant at the $1 \%$ level, ${ }^{* *}$ at the $5 \%$ level, and ${ }^{*}$ at the $10 \%$ level. 


\section{Figures}

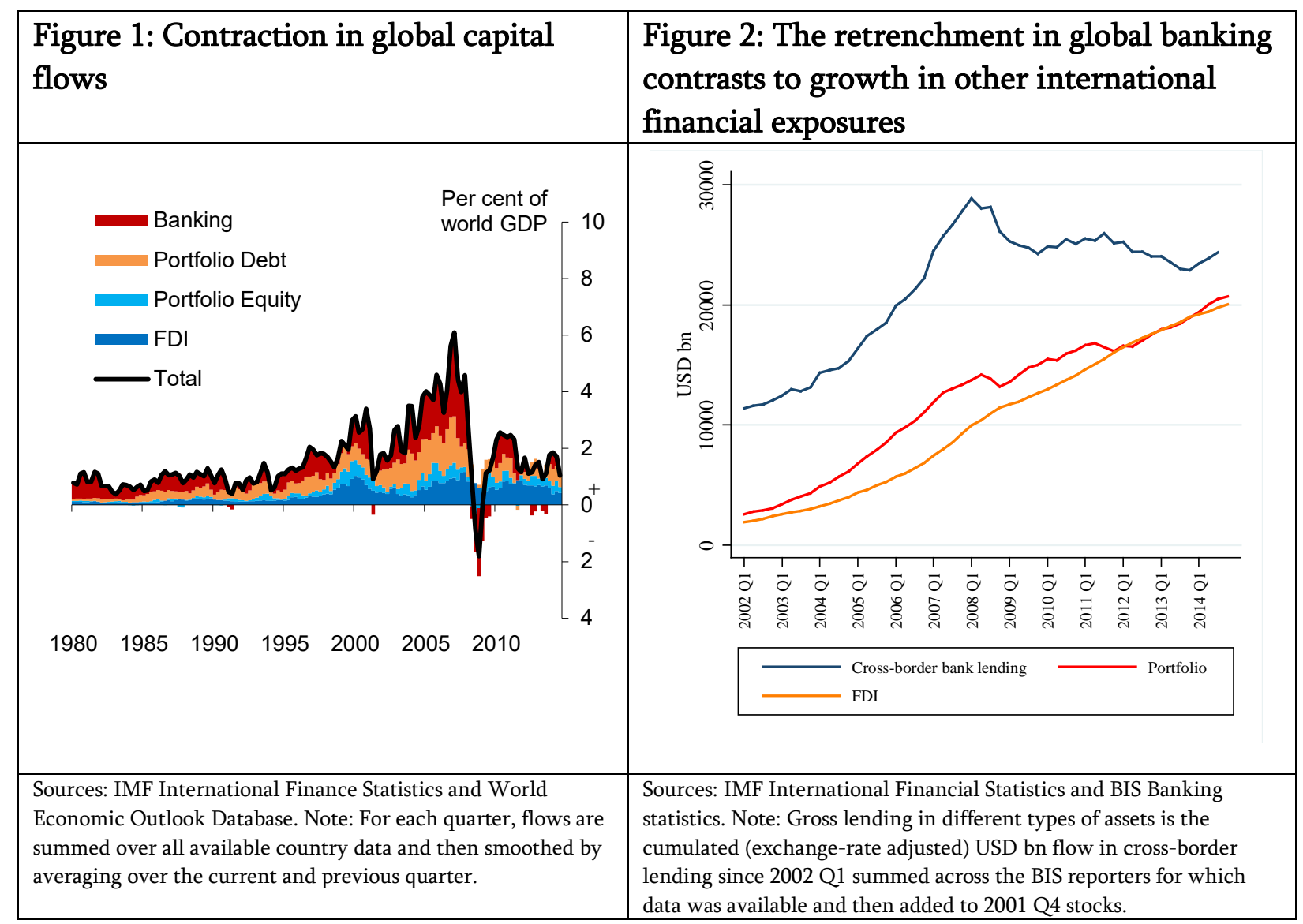

\section{Figure 3: Cross-border bank lending vs. domestic credit}

\section{Figure 3a: For all countries}
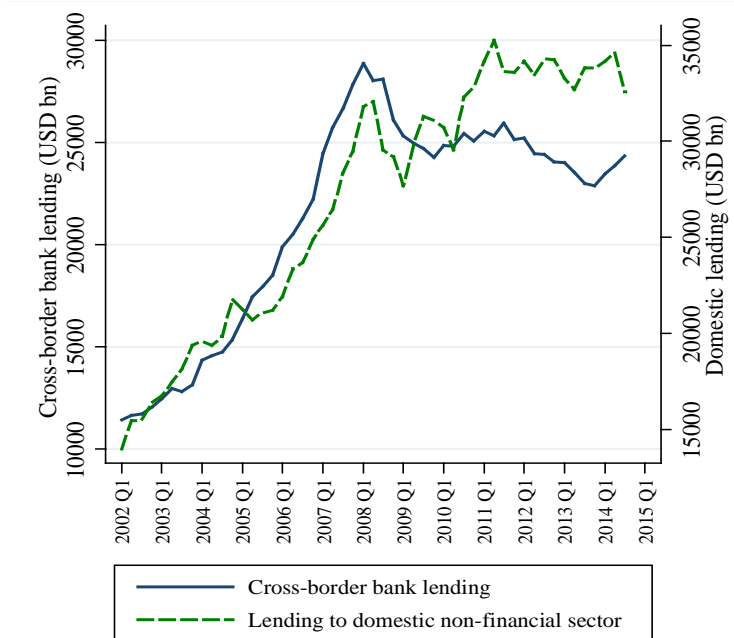

Figure 3b: For the UK
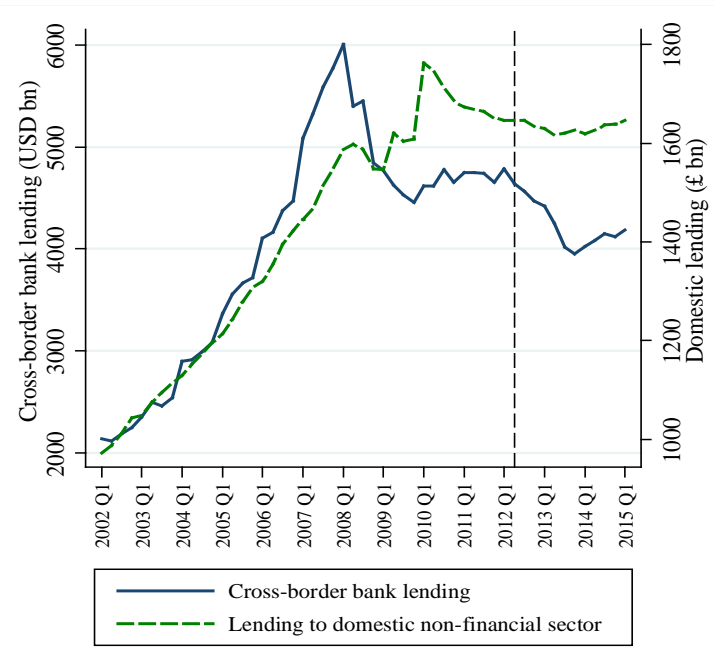

Source: BIS. Note: Gross bank-to-bank and bank-to-nonbank lending is the cumulated (exchange-rate adjusted) USD bn change in cross-border lending since 2002 Q1 summed across the BIS reporters for which data was available and then added to 2001 Q4 stocks. Domestic credit is the USD value of credit to the non-bank private sector summed across all BIS reporter (after converting into USD).
Source: BIS. Note: Gross bank-to-bank and bank-to-nonbank lending is the cumulated (exchange-rate adjusted) USD bn change in cross-border lending since 2002 Q1 and then added to 2001 Q4 stocks. Domestic credit is the sterling value of credit to the UK nonbank private sector. The dashed line indicates the introduction of the FLS. 


\begin{tabular}{|l|l|l|l|}
\hline \multicolumn{3}{|l|}{ Figure 4: Capital Requirements and Asset Purchase Announcements in the UK } \\
\hline 4a: UK Capital Requirements & $4 \mathrm{~b}$ : UK Asset Purchase Announcements \\
\hline & & & \\
\hline
\end{tabular}

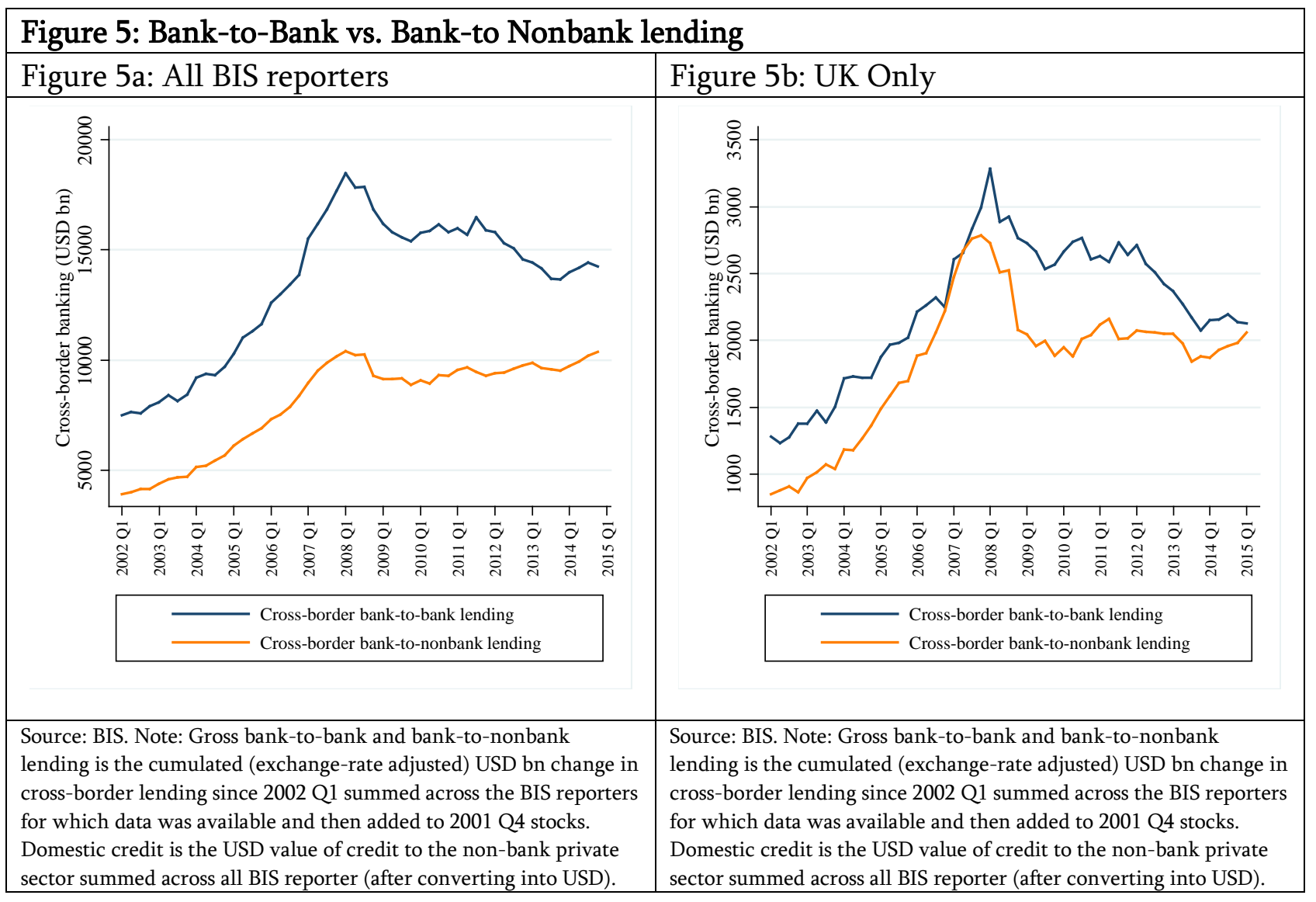




\section{Figure 6A}

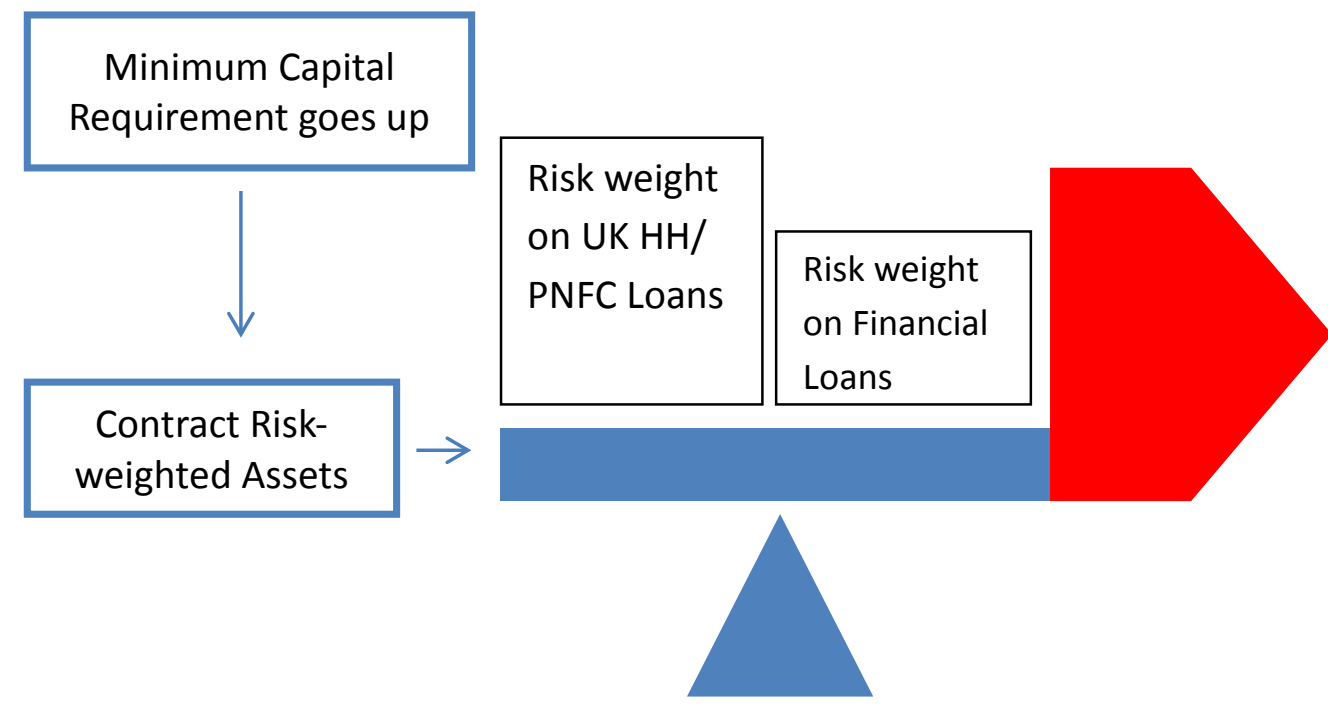

UK financial loans

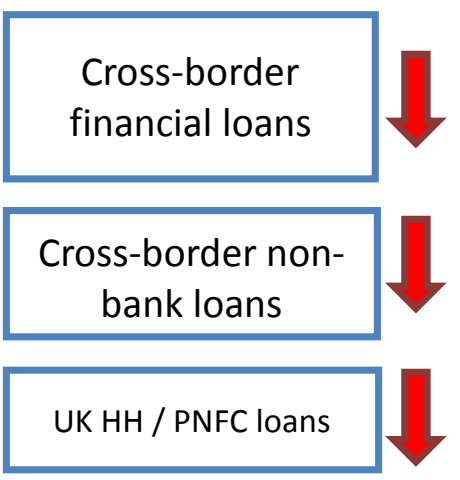

\section{Figure 6B}

\section{FLS Channel I: Lower loan rates $\rightarrow$ Lower PD $\Rightarrow$ Lower Risk Weight}

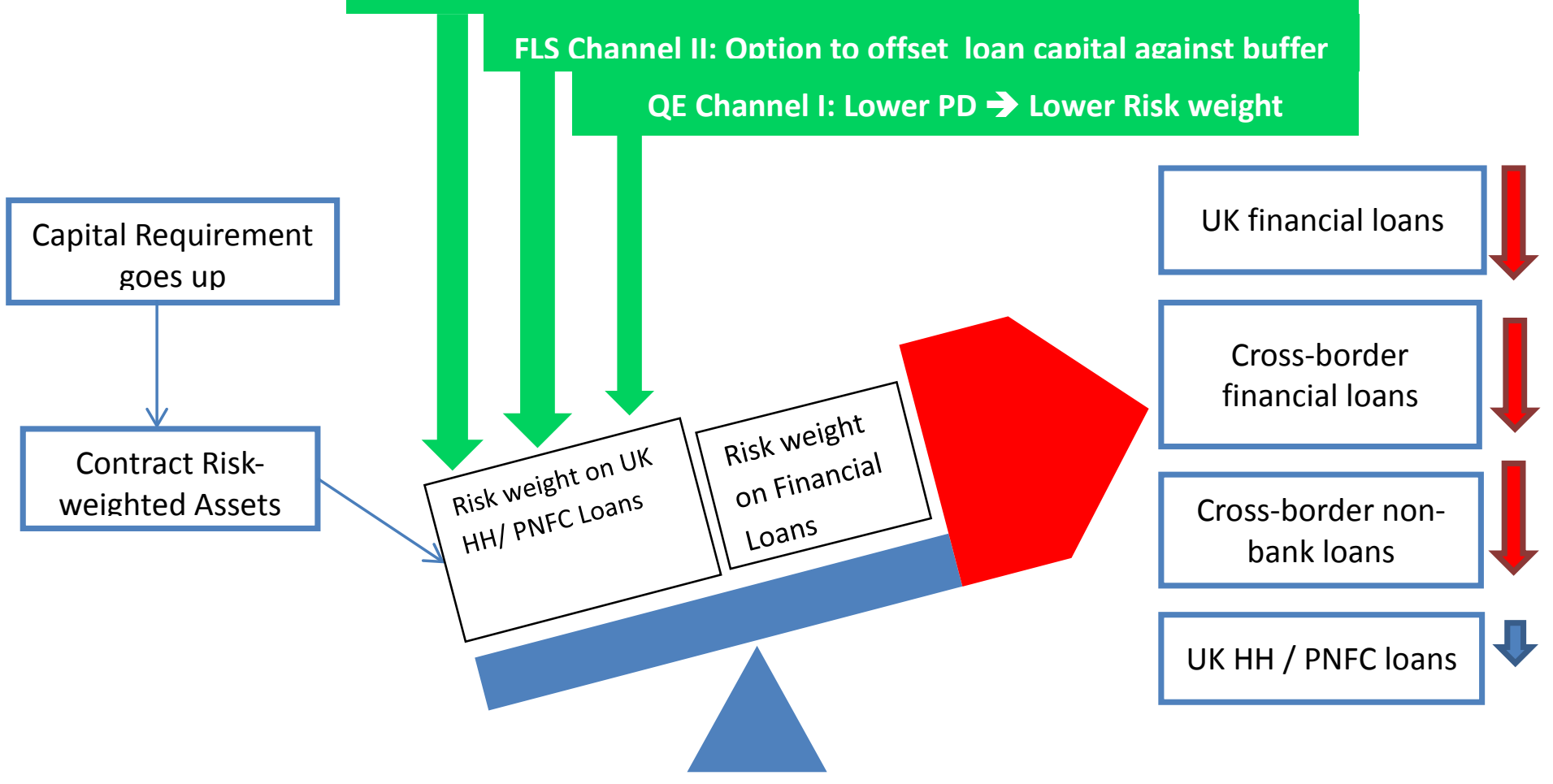



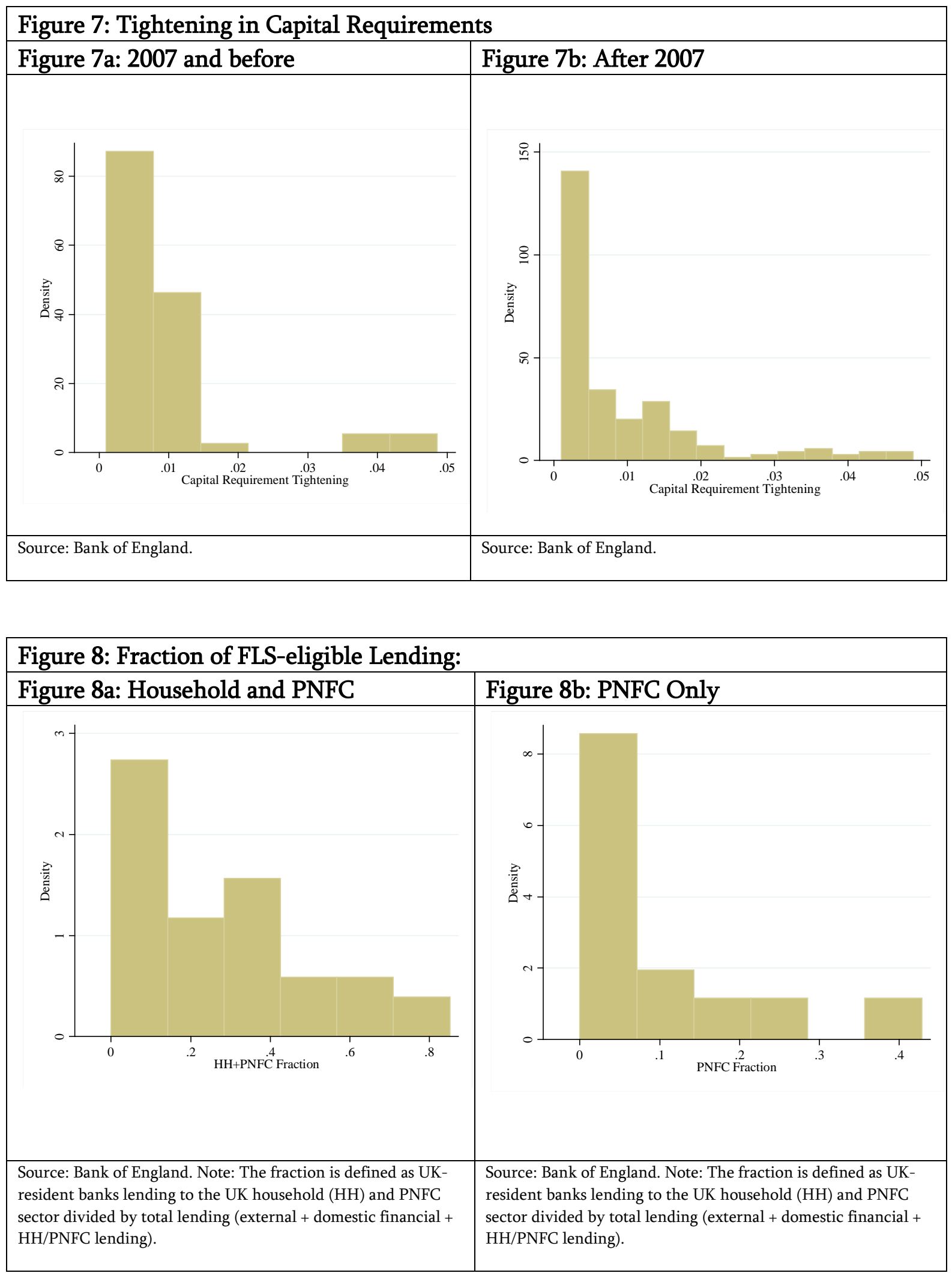


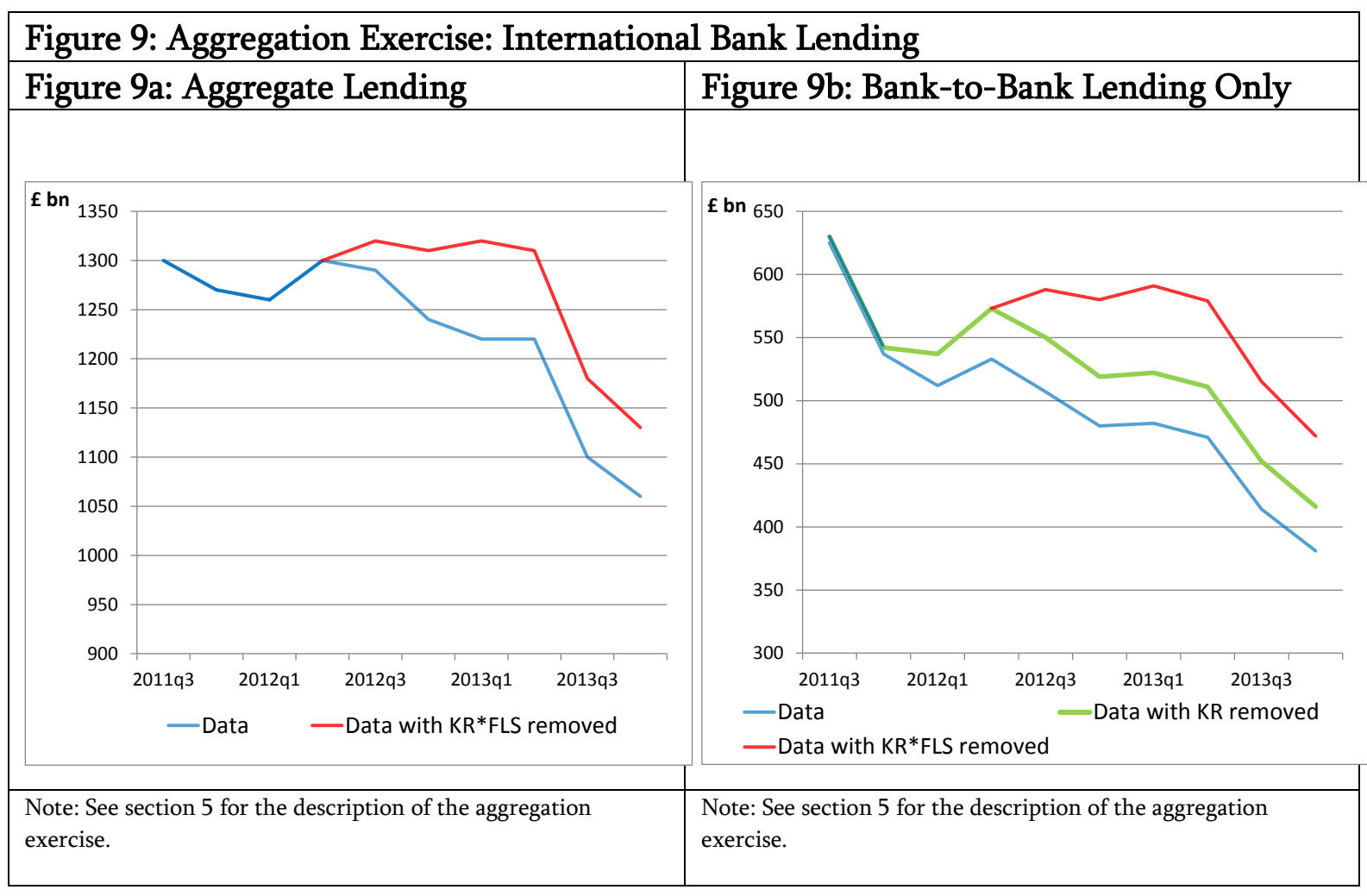

